\title{
PRESIDENTIAL NON-ENFORCEMENT OF CONSTITUTIONALLY OBJECTIONABLE STATUTES
}

\author{
DAWN E. JOHNSEN*
}

\section{INTRODUCTION}

In February 1996, Congress presented President Bill Clinton with a dilemma. The National Defense Authorization Act for Fiscal Year 1996 included a provision requiring the armed forces to discharge individuals infected with the human immunodeficiency virus ("HIV"), including asymptomatic individuals. ${ }^{1}$ President Clinton concluded that this provision "violate[d] equal protection by requiring the discharge of qualified service members living with HIV who are medically able to serve, without furthering any legitimate governmental purpose."2 Yet the bill also appropriated $\$ 265$ billion for military programs the President deemed "of great importance" to national security interests. ${ }^{3}$

President Clinton had vetoed an earlier version of the law due in part to the same HIV provision, ${ }^{4}$ but decided against a second veto because of the military's need for the money appropriated by the bill. ${ }^{5}$ President Clinton then

Copyright (C) 2000 by Dawn E. Johnsen

This article is also available at http://www.law.duke.edu/journals/63LCPJohnsen.

* Associate Professor of Law, Indiana University-Bloomington.

I am grateful to Walter Dellinger, Jeff Powell, Neil Kinkopf, and others at Duke Law School for the opportunity to participate in this interesting symposium. I would like to thank my fellow panelists and other participants in the symposium for their insights and also am grateful to Claudia Worrell Allen, David Barron, Patrick Baude, Jeannine Bell, Daniel Conkle, Marty Lederman, David Williams, and my research assistants, Ellen Meilaender and Robyn Holtzman, for helpful comments on drafts of this article.

1. See National Defense Authorization Act for Fiscal Year 1996, Pub. L. No. 104-106, § 567, 110 Stat. 186 (1996), repealed by Act of Apr. 26, 1996, Pub. L. No. 104-134, tit. II, § 2707(a)(1), 110 Stat. 1321, 1321-30 (codified as amended at 10 U.S.C. § 1177 (Supp. IV 1998)). The reader should be aware that I served as Acting Assistant Attorney General, 1997-98, and Deputy Assistant Attorney General, 1993-96, for the Office of Legal Counsel, U.S. Department of Justice. The Office of Legal Counsel provides legal advice, on behalf of the Attorney General, to the President and entities within the executive branch. While there, I participated on occasion in providing advice concerning how the President should respond to statutes he believed were unconstitutional, including the HIV provision. The views expressed in this article are my own, and not necessarily those of the Department of Justice.

2. Statement on Signing the National Defense Authorization Act for Fiscal Year 1996, 1 PUB. PAPERS: William J. Clinton 226, 227 (1996) [hereinafter Signing Statement].

3. Id. at 226 .

4. See Veto Message, H.R. DoC. No. 104-155 (1995), reprinted in 142 CONG. REC. H12 (daily ed. Jan. 3, 1996).

5. See Signing Statement, supra note 2, at 226. 
faced the prospect of either enforcing the HIV provision, which in his view would both violate the constitutional rights of more than a thousand members of the armed forces and diminish military effectiveness, or disregarding the dictates of an act of Congress he had signed into law.

President Clinton's dilemma was far from novel. More than a century earlier, the House of Representatives impeached President Andrew Johnson because he claimed the authority to disregard a statute that he viewed as unconstitutional. ${ }^{6}$ President Johnson fired the Secretary of War without first obtaining the consent of the Senate when consent arguably was required by the Tenure of Office Act, ${ }^{7}$ which Congress had enacted over President Johnson's veto. ${ }^{8}$ The Senate came within one vote of convicting and removing President Johnson from office for failing to enforce a law that the U.S. Supreme Court eventually agreed was unconstitutional. ${ }^{9}$ A contemporary example: Congress continues to enact provisions that purport to allow a single house (or committee) of Congress to block executive branch action despite the Supreme Court's declaration that such "legislative vetoes" are unconstitutional. ${ }^{10}$ Presidents routinely announce that they are not bound to comply with such provisions. ${ }^{11}$

This fundamental issue of the constitutional allocation of powers remains hotly contested. Constitutional commentators, as well as the political branches of our federal government, continue to debate the existence and parameters of the President's authority to refuse to enforce constitutionally objectionable statutes. $^{12}$ What should the President do if he believes enforcing a statute would violate the Constitution? In this article, I consider the legitimacy of what I will term "presidential non-enforcement," ${ }^{, 13}$ that is, whether and when the President may disobey an unambiguous congressional command enacted in conformity

6. See generally William H. REHNQUiST, GRAND INQUESTS: THE HistoriC IMPEACHMENTS OF JUSTICE SAMUEL CHASE AND PRESIDENT ANDREW JOHNSON 143-274 (1992).

7. See Tenure of Office Act, ch. 154, 14 Stat. 430 (1867).

8. See REHNQUIST, supra note 6 , at 210 .

9. See id. at 231-35. While the Tenure of Office Act was repealed in 1887, see id. at 261, the Court in 1926 declared unconstitutional a law that similarly required the President to obtain Senate consent before removing postmasters, see Myers v. United States, 272 U.S. 52 (1926).

10. See Immigration \& Naturalization Serv. v. Chadha, 462 U.S. 919, 944-59 (1983).

11. See, e.g., Statement on Signing the Treasury, Postal Service, and General Government Appropriations Act, 1994, 2 PUB. PAPERS: William J. CLINTON 1855 (1993).

Several provisions in H.R. 2403 condition the President's authority-and the authority of certain agency officials-to use funds appropriated by this Act on the approval of congressional committees. The Administration will interpret such provisions to require notification only, since any other interpretation of such provisos would contradict the Supreme Court ruling in INS v. Chadha.

Id. at $1855-56$.

12. I will use the term "constitutionally objectionable" statute or law as shorthand for a provision of an act of Congress that the President believes is unconstitutional under his best interpretation of the Constitution.

13. I prefer the term "presidential non-enforcement" to "executive review" or "presidential review," which some other commentators have used, see infra Part II.B, because it highlights that the President is not just interpreting the Constitution, but acting on his interpretation by not enforcing the law. 
with the constitutionally prescribed lawmaking process on the ground that the President believes the law is unconstitutional.

Presidential non-enforcement in this narrow sense differs significantly from some other far more common executive branch responses to constitutionally objectionable statutes. Presidents often avoid constitutional problems, as they should, through their interpretation of ambiguous statutes or through the exercise of enforcement discretion. ${ }^{14}$ These less controversial practices typically leave Congress free to consider the constitutional issue and enact more specific legislation if it disagrees with the President's views. Presidential nonenforcement, in the sense I will use the term, constitutes a more direct conflict with the core constitutional function of another branch of government. ${ }^{15}$

In Part II of this article, I review the two prevailing approaches to presidential non-enforcement found in the academic literature. Current views span the same constitutional spectrum as in the days of President Johnson's impeachment. At one end, proponents of what I will term "mandatory enforcement" of constitutionally objectionable statutes interpret the Constitution's directive that the President "take Care that the Laws be faithfully executed" ${ }^{16}$ as requiring the President to enforce duly enacted statutes unless directed otherwise by a court, regardless of the President's constitutional views. The Constitution confers on the President explicit and very limited authority to prevent the enforcement of laws he views as unconstitutional: $\mathrm{He}$ can "return," that is, veto, the bill, but Congress can enact the legislation by a

14. Presidents often use signing statements, issued at the time they sign bills into law, to announce any concerns about the constitutionality of provisions of the bills and how their enforcement of the provisions may be affected by their constitutional views. Past practice has included, as described by the U.S. Department of Justice, "statements that declare that the legislation (or relevant provisions) would be unconstitutional in certain applications; statements that purport to construe the legislation in a manner that would 'save' it from unconstitutionality; and statements that state flatly that the legislation is unconstitutional on its face." The Legal Significance of Presidential Signing Statements, 17 Op. Off. Legal Counsel 131, 132 (1993) (memorandum from Assistant Attorney General Walter Dellinger) [hereinafter Signing Statements Memorandum]. See generally id. at 132-33, 138-41 (citing examples).

15. I am grateful to Professor Peter Strauss for raising the importance of distinguishing these related executive branch practices. See generally Peter L. Strauss, The President and Choices Not to Enforce, 63 LAW \& CONTEMP. PROBS. 107 (Winter/Spring 2000). As I will discuss, presidential nonenforcement is particularly problematic when Congress passes a law after considering and rejecting the President's constitutional view, as when Congress overrides a constitutionally based veto. The same negating of congressional will does not result when the President applies standard and anticipated canons of statutory construction, for example, by construing an ambiguous statute to avoid a constitutional problem, or when the President allocates resources and sets enforcement priorities in ways the law does not preclude in order to avoid unconstitutional applications of a law. Indeed, Congress expects legislation to be enforced in conformity with these practices, unless it directs otherwise, and Presidents should exhaust available means of avoiding the constitutional dilemma posed by a constitutionally objectionable law. In extraordinary cases, though, the executive branch practices Professor Strauss discusses may be analogous to presidential non-enforcement and, in my view, subject to the same constitutional constraints. $C f$. Heckler v. Chaney, 470 U.S. 821, 833 n.4 (1985) (distinguishing the situation where an "agency has 'consciously and expressly adopted a general policy' that is so extreme as to amount to an abdication of its statutory responsibilities").

16. U.S. CONST. art. II, $\S 3$. The Take Care Clause, of course, does not require the President personally to execute the laws in a faithful manner, but to supervise executive branch officials to ensure the faithful execution of the laws. For ease of discussion, references to the President in this article also encompass other executive branch officials unless the context makes clear otherwise. 
two-thirds majority over his opposition. ${ }^{17}$

The competing view recognizes presidential authority to refuse to enforce any and all laws the President believes are unconstitutional. Proponents of this view, which I will term "routine non-enforcement" of constitutionally objectionable laws, stress that the President's paramount obligation in ensuring the faithful execution of the laws is to uphold the Constitution as the supreme law of the land. As the head of a coordinate branch of government, the President possesses the authority and responsibility to interpret the Constitution independently in the course of exercising his constitutional authorities. Under this view, the President not only may, but also typically must, disregard laws he views as unconstitutional.

The existing literature is extensive and impressive. Most commentators, however, find greater constitutional clarity than I believe exists-and the perceived clarity results in sharply divergent conclusions. Both viewsmandatory enforcement and routine non-enforcement-have the virtue of providing clear direction for the President's execution of the laws. But neither fully reflects the President's complex constitutional obligation when faced with a constitutionally objectionable statute.

In my view, the Constitution's text, history, and structure neither preclude nor authorize all presidential refusals to enforce constitutionally objectionable laws. Presidential non-enforcement does not directly or invariably conflict with Congress's ability to pass legislation or the judiciary's responsibility to "say what the law is" in the context of resolving justiciable controversies. ${ }^{18}$ The President, for example, promotes implementation of the Supreme Court's pronouncements by declining to enforce laws that are indistinguishable from those the Court has held unconstitutional; and at least where Congress passed the laws prior to the Court's articulation of the constitutional rule and without consideration of the constitutional issue, non-enforcement does not inappropriately interfere with Congress's lawmaking power. Presidential authority to decline to enforce constitutionally objectionable laws is, however, a power contemplated little, if at all, by the Framers, and it has the potential to disturb the constitutional equilibrium they established. I will argue that the Constitution is best interpreted not as providing a unitary answer across contexts, but as requiring the President to make sometimes difficult evaluations that depend on the specific statutory provision and the circumstances surrounding its enactment.

In Part III, I seek to shift the debate from a consideration of whether presidential non-enforcement authority exists in the abstract to a search for the principles that should govern how the President faithfully executes the law when confronted with a statute he believes unconstitutional. The method of constitutional interpretation central to this endeavor is a structural analysis that, in the words of Professor Charles Black, draws "inference from the structures

17. See id. art. I, $\S 7$, cl. 2 .

18. See Marbury v. Madison, 5 U.S. (1 Cranch) 137, 177 (1803). 
and relationships created by the Constitution in all its parts or in some principal part." ${ }^{19}$ The relevant inquiry should be: What presidential response to a constitutionally objectionable law is most in keeping with our constitutional structure and the values embodied therein?

I will examine past presidential practice and policy, which lends support to a context-dependent approach that is premised on reasoning from the constitutional structure. ${ }^{20} \quad$ Presidents have looked to the particular circumstances to guide non-enforcement decisions. They typically have enforced statutory provisions despite concerns about their constitutionality, but in extraordinary circumstances have refused to enforce provisions they believed were unconstitutional. ${ }^{21}$ Presidential practice evokes criticism from both sidesby some as an unconstitutional expansion of presidential power ${ }^{22}$ and by others as a politically driven compromise of principles. ${ }^{23} \mathrm{I}$ believe that, to the contrary, executive branch precedent suggests the beginnings of a theoretical framework for a context-dependent approach and the appropriate factors to guide presidential non-enforcement decisions.

The executive branch, however, has not yet provided a consistent, persuasive, and comprehensive articulation of the principles that support limited presidential non-enforcement. Part III seeks to advance that effort. Proponents of routine non-enforcement emphasize a useful starting point by focusing on the roles of the President and Congress, as coordinate branches of government, in the process of constitutional interpretation. I agree with the assessment that the U.S. legal system at present focuses inordinately on the judiciary as the appropriate realm for constitutional interpretation. Congress and the President also are obliged to uphold, and thus by necessity to interpret, the Constitution, and the process of constitutional interpretation benefits from the thoughtful participation of the elected representatives of the people in the

19. Charles L. Black, JR., Structure and Relationship in CONSTITUtional LAW 7 (1969); see also PHILIP BOBBITT, CONSTITUTIONAL INTERPRETATION 11-22 (1991); H. Jefferson Powell, The President's Authority Over Foreign Affairs: An Executive Branch Perspective, 67 GEO. WASH. L. REV. 527, 530-35 (1999) (discussing the role of structural reasoning in the executive branch's approach to constitutional issues that arise in areas of foreign affairs and national security).

20. Support can be found in particular in several legal memoranda prepared by the U.S. Department of Justice during the last quarter century and most recently during President Clinton's Administration. See, e.g., Presidential Authority to Decline to Execute Unconstitutional Statutes, 18 Op. Off. Legal Counsel 199 (1994) (memorandum from Assistant Attorney General Walter Dellinger) [hereinafter 1994 Dellinger Memorandum]; The Attorney General's Duty to Defend and Enforce Constitutionally Objectionable Legislation, 4A Op. Off. Legal Counsel 55 (1980) (memorandum from

Attorney General Benjamin R. Civiletti) [hereinafter 1980 Civiletti Memorandum].

21. According to one survey,

In the nearly 200 years from 1789 to $1981, \ldots$ [i]n only 20 cases did the President fail to comply with the law.... As recently as 1966, Chief Executives had ignored allegedly unconstitutional laws on only 9 occasions. Not until the last two decades did executive defiance begin to reach significant proportions.

Christopher N. May, Presidential Defiance of "Unconstitutional” Laws: Reviving the Royal Prerogative,

21 HASTINGS CONST. L.Q. 865, 977 (1994).

22. See, e.g., id. at 867-69, 977-86.

23. See, e.g., Michael Stokes Paulsen, The Most Dangerous Branch: Executive Power to Say What the Law Is, 83 GEO. L.J. 217, 340 (1994). 
public dialogue about the meaning of the Constitution. In some circumstances, the President possesses the authority to act solely on his independent assessment of the meaning of the Constitution, such as when the President exercises his veto or pardon powers.

When, however, the subject of the President's constitutional interpretation is whether to enforce the clear dictates of a statute, the constitutional structure dictates not independence but restraint. The Constitution not only obligates the President to ensure that the laws are faithfully executed, but also explicitly and unambiguously prescribes how the President and Congress are to take part in determining the content of the laws and how they are to resolve disputes over what the law should be. The President must exercise executive authority in a manner that respects those structural prescriptions.

Part III concludes by suggesting two principles that should be used to define presidential non-enforcement authority. Considered in combination, they support what typically is described as a presumption of constitutionality, but in this context may be more precisely termed a presumption of enforceability of statutes. The presumption should be overcome only when non-enforcement would allow the President responsibly and usefully to advance constitutional norms and dialogue regarding their definition. In making non-enforcement decisions, the President should be respectful of the functions and competencies of the other branches and should not seek to impose his own views to the exclusion of those of Congress and the courts.

The first principle requires that presidential non-enforcement policy respect the constitutionally prescribed lawmaking process. While limited instances of non-enforcement can be reconciled with the lawmaking process, routine nonenforcement cannot. If Presidents were to disregard laws routinely based solely on their own constitutional views, they would deprive Congress of the ability to enact effective legislation premised on its considered constitutional views to the contrary-even by a two-thirds majority over a constitutionally based veto. Routine non-enforcement, moreover, could grossly distort the constitutionally preferred means for the President to promote the Constitution's supremacy over unconstitutional laws: Presidents would have little incentive to veto unconstitutional bills, or to work with Congress to cure constitutional defects in pending bills and repeal unconstitutional laws. Finally, in some cases, by not enforcing a statute, the President would render the constitutionality of the law nonjusticiable, depriving Congress of the possibility of presenting its competing views in defense of the law.

The second principle requires that presidential non-enforcement policy promote the Constitution and the determination of constitutional meaning, and not simply the President's own constitutional views. The courts typically are better suited than the President to the task of constitutional interpretation. On certain issues, though, the President or Congress may possess an interpretive advantage because of institutional expertise or judicial doctrines that result in the underenforcement of constitutional norms. Presidential non-enforcement 
policy should respect judicial precedent and Congress's considered judgments about the meaning of the Constitution, but afford greater weight to the President's views when the President possesses special institutional expertise of relevance.

In Part IV, I seek to translate these two principles into specific factors to help guide presidential non-enforcement decisions. A review of executive branch practice and policy reveals three factors that the executive branch most often has cited as relevant to non-enforcement decisions: how clear the constitutional infirmity is, whether non-enforcement will affect the justiciability of the constitutional issue, and whether the law encroaches on presidential power. I assess those factors and, in the course of that assessment, develop six questions that I believe are most helpful in determining the President's constitutional obligations when called upon to enforce a law he believes is unconstitutional: (1) how clear is the law's constitutional defect; (2) does the President possess institutional expertise relevant to resolving the constitutional issue, and what are the relative interpretive abilities of the three branches; (3) did Congress actually consider the constitutional issue in enacting the law; (4) what is the likelihood of judicial review and how would non-enforcement affect that likelihood; (5) how serious is the harm that would result from enforcement; and (6) are repeal of the statute or non-defense of the statute against legal challenge effective alternatives to non-enforcement?

While an application of these principles and questions typically will provide clear guidance, I conclude in Part V by considering a hard case, indeed, one of the most difficult non-enforcement decisions a President has faced: President Clinton's response to the statutory requirement that he discharge members of the military who were HIV-positive. To complete that story, President Clinton decided that the constitutionally appropriate response was to seek repeal of the provision and, if unsuccessful, to comply with the law but not defend it in the already-planned legal challenge. Congress would be free to file a brief defending the law. The President was successful in working with Congress to repeal the provision before the law's effective date, when the President would have been required to discharge the service members.

The system worked at its best in this case. The President encouraged debate over the law's constitutionality and promoted his constitutional view through the lawmaking process, rather than by unilaterally blocking the provision, which in this case also would have rendered the dispute over the law's constitutionality nonjusticiable. The success of the repeal effort, however, masks the extraordinary closeness of the question. Had the repeal effort failed, more than a thousand HIV-positive individuals faced the loss of their jobs and benefits. Also weighing in favor of non-enforcement, the President in a sense was better situated than the courts to protect the constitutional interests of the service members. The President possessed expertise as commander in chief relevant to assessing the constitutionality of the provision, while the courts probably would have upheld the provision under judicial doctrines that reflect 
deference to Congress, which in this instance did not explicitly consider the constitutional issue during the legislative process.

\section{II}

\section{BASIC TERMS OF THE DEBATE}

The academic literature on presidential non-enforcement is extensive and rich, with important contributions from the three branches of government. I will not attempt to assess existing analysis comprehensively, but instead will review trends in the debate as a vehicle for suggesting a reorientation of the debate. With the caveat that I am not addressing all views or some significant subtleties in views, I believe that most of the academic literature fairly and usefully can be described as following one of two approaches: mandatory enforcement or routine non-enforcement of constitutionally objectionable statutes. $^{24}$

\section{A. Mandatory Enforcement of Constitutionally Objectionable Statutes}

One approach to presidential non-enforcement interprets the Constitution as requiring the President to execute acts of Congress, unless directed otherwise by a court of law, even when the President believes a law violates the Constitution. The only federal appellate court squarely to consider the legitimacy of presidential non-enforcement adopted a version of this mandatory enforcement approach. The U.S. Court of Appeals for the Ninth Circuit held that the executive branch acted unlawfully by refusing to comply with a statute the President believed unconstitutionally encroached on executive power. ${ }^{25}$ The Ninth Circuit not only disagreed with the executive's constitutional analysis, but awarded attorneys' fees against the government for acting in bad faith by intentionally violating the statute. ${ }^{26}$

The Ninth Circuit equated presidential non-enforcement with the presidential assertion of an absolute line-item veto. ${ }^{27}$ The Constitution confers on the President a role in the legislative process: the authority either to sign a bill into law or to return it, whereupon it will be subject to reconsideration and

24. I emphasize that not all commentators are easily placed in the two categories set forth here, and some of the commentators I describe as representative of these two categories would recognize limited exceptions to the position I ascribe to them. I will elaborate on the views of particular commentators where relevant to the development of an alternative approach to presidential nonenforcement.

25. See Lear Siegler, Inc. v. Lehman, 842 F.2d 1102 (9th Cir. 1988), withdrawn in part on other grounds, 893 F.2d 205 (9th Cir. 1989) (as amended, Jan. 10, 1990) (en banc) (per curiam). The law at issue empowered the Comptroller General, an agent of Congress, to place a hold of indefinite duration on the executive branch's ability to award certain contracts. See also Ameron, Inc. v. United States Army Corps of Engineers, 787 F.2d 875, 889 (3d Cir. 1986) ("This claim of right for the President to declare statutes unconstitutional and to declare his refusal to execute them, as distinguished from his undisputed right to veto, criticize, or even refuse to defend in court, statutes which he regards as unconstitutional, is dubious at best.").

26. See Lear Siegler, 842 F.2d at 1115-26.

27. See id. at 1124 . 
enactment by a two-thirds vote of Congress. ${ }^{28}$ The President thus possesses a qualified-not absolute-veto, and Congress possesses the ultimate authority to enact a law over a presidential veto. The President's asserted non-enforcement authority, the court found, would expand the President's legislative role by giving him a "de facto line item veto" in derogation of the constitutionally prescribed "single, finely wrought and exhaustively considered, procedure" for enacting legislation. ${ }^{29}$ The court further found that by refusing to enforce the provision at issue, the President unconstitutionally assumed the power of judicial review, a role constitutionally assigned to the judicial branch. ${ }^{30}$ Finally, the court concluded that the Take Care Clause did not support the asserted expansion in the President's role. ${ }^{31}$

The Ninth Circuit's conclusion that presidential non-enforcement constitutes an unconstitutional assertion of both legislative and judicial authority does not, in my view, appropriately conceptualize the constitutional dilemma created for the President by constitutionally objectionable statutes. A presidential refusal to enforce a statutory provision on constitutional grounds does not effect a veto of that provision and is not best viewed as an exercise of legislative authority. Article I's "finely wrought" lawmaking process is completed-possibly long completed-before the President's non-enforcement decision. Furthermore, presidential non-enforcement does not deprive the judiciary of its Article III powers to resolve any justiciable cases or controversies that may arise. Article III does not confer on the federal courts exclusive authority to interpret the Constitution, and the President does not usurp judicial power by acting on his constitutional views in the course of exercising executive authority. Moreover, the federal courts have no constitutional claim to resolve any particular case or controversy. ${ }^{32}$

Academic and executive branch commentary usually correctly locate the heart of the controversy not in Article I or Article III, but in the scope of the President's executive power and the meaning of Article II's command that the President "take Care that the Laws be faithfully executed." 33 Edward Corwin's view is representative of those who interpret the duty to execute the laws faithfully as requiring execution of the laws as enacted: "[O]nce a statute has been duly enacted, whether over [the President's] protest or with his approval, he must promote its enforcement by all the powers constitutionally at his

28. See U.S. CONST. art. I, $\S 7, \mathrm{cl} .2$.

29. Lear Siegler, 842 F.2d at 1123-24 (quoting Immigration \& Naturalization Serv. v. Chadha, 462 U.S. 919, 951 (1983)).

30. See id. at 1125 .

31. See id. at 1124-25. A subcommittee of the U.S. House of Representatives also condemned the President's actions, in part on the same view that the President had seized legislative power outside the constitutional process of lawmaking. See H.R. Rep. No. 99-138 (1985).

32. Although the Ninth Circuit's analysis fairly may be criticized, and its decision to award attorneys' fees was unjustified, the President's refusal to enforce the law does raise constitutional concerns closely related to those the Ninth Circuit identified. See infra Part III.C.1.

33. U.S. CONST. art. II, $\S 3$. 
disposal unless and until enforcement is prevented by regular judicial process." ${ }^{{ }^{34}}$ More recently, Christopher May equated presidential non-enforcement with "a suspending power, one of the royal prerogatives exercised by the kings of England, which was wrested from the crown less than a century before the American Revolution." ${ }^{\prime 35}$

Its history and purpose confirm that the Take Care Clause denies the President any dispensing or suspending power, that is, the power selectively to enforce laws. The President clearly may not refuse to enforce a law because he disapproves of the policy behind it. ${ }^{36}$ But this does not resolve the narrower question that arises when the basis for non-enforcement is itself an obligation to uphold the Constitution. The Take Care Clause and the constitutional structure are best interpreted as limiting, but not precluding, presidential nonenforcement of constitutionally objectionable laws. ${ }^{37}$

\section{B. Routine Non-Enforcement of Constitutionally Objectionable Statutes}

Representative of the approach I have termed routine non-enforcement of constitutionally objectionable laws is the position adopted in a 1992 memorandum by Acting Assistant Attorney General Timothy E. Flanigan of the Department of Justice ("1992 Flanigan Memorandum"), which described presidential non-enforcement authority in sweeping terms that would seem to allow the President to refuse to enforce any law that in his view is unconstitutional. ${ }^{38}$ The 1992 Flanigan Memorandum conceded, as it must, that the Take Care Clause requires the President to ensure the faithful execution of the laws, but emphasized what also clearly is true-that the Constitution is among "the Laws" the President must faithfully execute. It then argued that the Constitution dictates the hierarchy of laws the President is to follow in cases

34. EdWARd S. CORWIN, THE PRESIDENT: OFFICE AND POWERs 66 (4th rev. ed. 1957).

35. May, supra note 21, at 869; see also 3 WESTEL W. WilloughBY, THE CONSTITUTIONAL LAW OF THE UNITED STATES 1503 (2d ed. 1929) ("The President has not been given the power to defeat the will of the people or of the legislature as embodied in law."); Eugene Gressman, Take Care, Mr. President, 64 N.C. L. REV. 381, 382 (1986) ("[O]nce a bill has passed through all the constitutional forms of enactment and has become a law, perhaps even over a presidential veto grounded on constitutional objections, the President has no option under article II but to enforce the measure faithfully."); Arthur S. Miller, The President and Faithful Execution of the Laws, 40 VAND. L. REV. 389, 398 (1987) ("To 'execute' a statute... emphatically does not mean to kill it. Execution means implementation.").

36. See Kendall v. United States ex rel. Stokes, 37 U.S. (12 Pet.) 524, 613 (1838) ("To contend that the obligation imposed on the President to see the laws faithfully executed, implies a power to forbid their execution, is a novel construction of the constitution, and entirely inadmissible.").

37. See May, supra note 21, at 876-81.

38. Issues Raised by Provisions Directing Issuance of Official or Diplomatic Passports, 16 Op. Off. Legal Counsel 18, 31-36 (1992) (memorandum from Acting Assistant Attorney General Timothy E. Flanigan) [hereinafter 1992 Flanigan Memorandum]; see also Issues Raised by Foreign Relations Authorization Bill, 14 Op. Off. Legal Counsel 37, 46-52 (1990) (memorandum from Assistant Attorney General William P. Barr) [hereinafter 1990 Barr Memorandum]. Although the decisions not to enforce the statutes at issue in the 1992 Flanigan and 1990 Barr Memoranda could have been defended on the narrower ground, noted but not relied upon in the memoranda, that the statutes encroached on the President's constitutional powers, see infra Part IV.A.3, the justifications the memoranda offer for nonenforcement would seem to apply to any law the President believes is unconstitutional. 
of conflict through the Supremacy Clause ${ }^{39}$ and the requirement that the President swear or affirm to "preserve, protect and defend the Constitution." When enforcement of a statute would violate the Constitution, "[t]he resolution of this conflict is clear: The President must heed and execute the Constitution, the supreme law of our Nation." ${ }^{41}$ Indeed, "an unconstitutional statute ... is simply not a law at all," and therefore "cannot be one of the 'Laws' that the President must faithfully execute." 42 More than a century earlier, Attorney General Black similarly described the President's non-enforcement authority: "Every law is to be carried out so far forth as is consistent with the Constitution, and no further. The sound part of it must be executed, and the vicious portion of it suffered to drop." ${ }^{43}$

The recognition that the President must uphold the Constitution and that an unconstitutional law is "no law at all" is, however, insufficient to establish presidential authority to disregard "unconstitutional" laws, for it begs a critical question: "unconstitutional" in whose view? Clearly, the President must take care that the commands of the Constitution are faithfully executed, but the difficulty arises, of course, when those commands are unclear. Congress, no less than the President, is obligated to uphold the Constitution, and its passage of an act is viewed generally as a congressional determination of constitutionality. ${ }^{44}$ When the executive and legislative branches disagree, and the judicial branch has not spoken, which branch's view of the Constitution should prevail? Who decides?

A number of academic commentators in recent years have reached the same conclusion as the 1992 Flanigan Memorandum-when executing the law, the President decides-while recognizing the need for a justification for allowing the executive's constitutional views to prevail. Arguments for routine nonenforcement typically are grounded in a theory of constitutional interpretive authority that emphasizes that the executive is a coordinate, not subordinate, branch of government with coequal authority to interpret the Constitution in exercising executive authority, a power comparable to the authority of Congress and the judiciary in their spheres. In a powerful defense of presidential nonenforcement authority, Judge Frank Easterbrook of the U.S. Court of Appeals for the Seventh Circuit likened what he called "presidential review" to judicial review: "The tough question in Marbury was not whether the Constitution trumps a statute, but who interprets the meaning of the Constitution." 45 The lesson of Marbury, according to Judge Easterbrook, is "[e]very man for himself.' Each official owes the same duty to the hierarchy and must make his

39. See U.S. CONST. art. VI, § 2 .

40. Id. art. II, § 1, cl. 8 .

41. 1992 Flanigan Memorandum, supra note 38, at 32.

42. $I d$.

43. Memorial of Captain Meigs, 9 Op. Att'y Gen. 462, 469 (1860) [hereinafter 1860 Black Opinion].

44. See infra notes $114-15$ and accompanying text.

45. Frank H. Easterbrook, Presidential Review, 40 CASE W. RES. L. REV. 905, 919 (1990). 
own decision." ${ }^{46}$

Other commentators also have relied on analogies to judicial review and theories of coordinate interpretive authority to advance the case for what they term "presidential" or "executive" review. Professor John Harrison, for example, explored Alexander Bickel's insight that the real issue confronting the Court in Marbury was who decides whether a statute conflicts with the Constitution. $^{47}$ An adequate defense of judicial review must establish not only that the Constitution is supreme, but also that the courts rather than Congress should have final authority to say what the Constitution means in relation to a statute. An analogous issue is posed when the President is confronted with a constitutionally objectionable statute. Harrison identified as a default rule for any legal interpreter the freedom independently to interpret the Constitution unless there exists a finality rule that requires accepting another's interpretation. $^{48}$ Harrison concluded that executive review is appropriate for the very reason judicial review is justified: There is no special finality rule that allows Congress (unlike, perhaps, the judiciary) to bind another branch (nor for that matter, any individual) to its views regarding the constitutionality of statutes. ${ }^{49}$

Professor Michael Paulsen's version of executive review takes the additional controversial step of recognizing that the President has the constitutional responsibility not only to disregard unconstitutional statutes, but also to decline to enforce judgments issued by courts when the President's constitutional views so dictate. ${ }^{50}$ Paulsen premised his rejection of any notion of judicial supremacy on the theory that the three coequal branches of government possess coordinate and independent interpretive responsibility. ${ }^{51}$ The President therefore has the duty to interpret the Constitution independently in the exercise of all executive functions and even should disregard a judicial order he believes is inconsistent with the Constitution.

46. Id. at 919-20.

47. John Harrison, The Constitutional Origins and Implications of Judicial Review, 84 VA. L. REV. 333, 356-63 (1998). Other important defenses of presidential non-enforcement authority include the following:

Suppose that the President determines that a statute is unconstitutional, even though Congress, the courts, and prior presidents (or even the same President at a prior time) all determined that it was constitutional. Must the President refuse to enforce that statute? Modern departmentalists have uniformly answered "Yes," and they are right.

Gary Lawson \& Christopher D. Moore, The Executive Power of Constitutional Interpretation, 81 IowA L. REV. 1267, 1303 (1996).

$[\mathrm{T}]$ he President has a duty, derived at the very least from the oath of office, to interpret the Constitution lest the oath be violated by enforcing an unconstitutional statute. ... I think it is deeply paradoxical to argue that the President is under a duty to enforce what he or she believes to be an unconstitutional statute.

Sanford Levinson, Constitutional Protestantism in Theory and Practice: Two Questions for Michael Stokes Paulsen and One for his Critics, 83 GEO. L.J. 373, 378-79 (1994).

48. See Harrison, supra note 47 , at 362-63.

49. See id. at 367-69.

50. Paulsen, supra note 23.

51. See id. at 228-40. 
The theory behind these calls for routine presidential non-enforcement would require, rather than merely permit, Presidents to refuse to enforce laws that are in their view unconstitutional. ${ }^{52}$ The President's obligation to uphold the Constitution above all laws would require him to assess whether a statute is constitutional and to refuse to enforce it if he is convinced it is unconstitutional. He could not pick and choose his fights with Congress, but would be constitutionally compelled periodically to threaten the efficacy of Congress's core lawmaking function-for Congress not infrequently enacts laws of questionable constitutionality. For a President to choose to enforce a statute he believed was unconstitutional would constitute a dereliction of his constitutional obligation. ${ }^{53}$

Contemporary commentators find support for routine non-enforcement of constitutionally objectionable laws in statements of the framers of the Constitution $^{54}$ and several prominent Presidents. Thomas Jefferson, Andrew

52. See Michael B. Rappaport, The President's Veto and the Constitution, 87 Nw. U. L. REV. 735 , 767-76 (1993).

One aspect of presidential review has not received sufficient attention-its nondiscretionary character. If the Constitution requires the President to set aside unconstitutional statutes, then the President has no more discretion to enforce an unconstitutional statute than does a court. The President must not enforce unconstitutional statutes even when it is politically unpopular to do so.

Id. at 769 .

53. According to Professor Paulsen, for example, "the President's oath requires that the President exercise full legal review over the lawfulness of other branches' acts whenever he is called on to employ the executive power in furtherance of those acts." Paulsen, supra note 23, at 262. Professor Paulsen went on, however, to temper his theory of coordinate review with what he described as principles of "executive restraint" to guide non-enforcement decisions. I agree with Professor Christopher Eisgruber's characterization that, in light of the starkly different tone of these principles, "there seem to be two theories" in Paulsen's article: "a Jekyll-Theory and a Hyde-Theory." Christopher L. Eisgruber, The Most Competent Branches: A Response to Professor Paulsen, 83 GEO. L.J. 347, 364 (1994). I also agree with Professor Eisgruber's assessment that, despite this difference in tone, Professor Paulsen's principles of restraint would allow a President to enforce a provision he firmly believed was unconstitutional only in the extremely limited circumstance when the only alternative is "a selfdestructive and system-destructive course of uncompromising independence." $I d$. at 365 (quoting Paulsen, supra note 23, at 338).

54. Advocates of executive review sometimes rely unduly on a statement by James Wilson during the Pennsylvania debates on the ratification of the Constitution:

I had occasion, on a former day ... to state that the power of the Constitution was paramount to the power of the legislature, acting under that Constitution. For it is possible that the legislature ... may transgress the bounds assigned to it, and an act may pass in the usual mode, notwithstanding that transgression; but when it comes to be discussed before the judges-when they consider its principles and find it to be incompatible with the superior powers of the Constitution, it is their duty to pronounce it void. ... In the same manner, the President of the United States could shield himself and refuse to carry into effect an act that violates the Constitution.

1992 Flanigan Memorandum, supra note 38, at 33-34 (quoting 2 THE DOCUMENTARY HISTORY OF THE RATIFICATION OF THE CONSTITUTION 450-51 (Merrill Jensen ed., 1976) (statement of Dec. 1, 1787)) (second emphasis added in 1992 Flanigan Memorandum); see also Easterbrook, supra note 45, at 921 (quoting James Wilson). But see Paulsen, supra note 23, at 226-27 ("It is not my contention that the framers or the founding generation specifically intended the consequences I defend.... Rather, my thesis is that executive review follows logically as a consequence of the structural premises the framers embraced ....").

Attorney General Civiletti's assessment seems correct: "The available evidence concerning the intentions of the Framers lends no specific support to the proposition that the Executive has a 
Jackson, and Abraham Lincoln all offered eloquent and often-quoted defenses of the President's authority, at least in some circumstances, to act on his own constitutional views. Although informed in each instance by a particular controversy, they employed reasoning worthy of consideration in support of routine non-enforcement. In a memorandum to Abigail Adams, President Jefferson explained his justification for pardoning all those convicted under the Sedition Act of 1798, which Jefferson viewed as unconstitutional, but which lower federal courts at the time had upheld: ${ }^{55}$

You seem to think it devolved on the judges to decide on the validity of the sedition law. But nothing in the Constitution has given them a right to decide for the Executive, more than to the Executive to decide for them. Both magistracies are equally independent in the sphere of action assigned to them. The judges, believing the law constitutional, had a right to pass a sentence of fine and imprisonment; because that power was placed in their hands by the Constitution. But the Executive, believing the law to be unconstitutional, was bound to remit the execution of it; because that power has been confided to him by the Constitution. That instrument meant that its co-ordinate branches should be checks on each other. But the opinion which gives to the judges the right to decide what laws are constitutional, and what not, not only for themselves in their own sphere of action, but for the Legislature \& Executive also, in their spheres, would make the judiciary a despotic branch. ${ }^{56}$

President Jackson described as follows his understanding of presidential authority to veto a bill on constitutional grounds, regardless of a Supreme Court ruling reaching a contrary conclusion on the constitutional issue presented by the bill:

The Congress, the Executive, and the Court must each for itself be guided by its own opinion of the Constitution. Each public officer who takes an oath to support the Constitution swears that he will support it as he understands it, and not as it is understood by others. It is as much the duty of the House of Representatives, of the Senate, and of the President to decide upon the constitutionality of any bill or resolution which may be presented to them for passage or approval as it is of the supreme judges when it may be brought before them for judicial decision. The opinion of the judges has no more authority over Congress than the opinion of Congress has over the judges, and on that point the President is independent of both. The authority of the Supreme Court must not, therefore, be permitted to control the Congress or the Executive when acting in their legislative capacities, but to have only such influence as the force of their reasoning may deserve. ${ }^{57}$

President Lincoln, in his First Inaugural Address, in the wake of the Supreme Court's Dred Scott ${ }^{58}$ decision, described his view of presidential interpretive authority:

I do not forget the position assumed by some that constitutional questions are to be

constitutional privilege to disregard statutes that are deemed by it to be inconsistent with the Constitution." 1980 Civiletti Memorandum, supra note 20, at 58.

55. The Supreme Court, of course, ultimately agreed with Jefferson that the Sedition Act violated the Constitution, but that was not until 166 years after the Act's passage. See New York Times v. Sullivan, 376 U.S. 254, 276 (1964).

56. Memorandum to Abigail Adams (Sept. 11, 1804), in 8 THE WRITINGS OF THOMAS JEFFERSON 311 (Paul Leicester Ford ed., G.P. Putnam's Sons 1897).

57. Andrew Jackson, Veto Message (July 10, 1832), in 2 A COMPILATION OF THE MEsSAGES AND PAPERS OF THE PRESIDENTS 1789-1897, at 582 (James D. Richardson ed., 1900).

58. Dred Scott v. Sandford, 60 U.S. (19 How.) 393 (1856). 
decided by the Supreme Court, nor do I deny that such decisions must be binding in any case upon the parties to a suit as to the object of that suit, while they are also entitled to a very high respect and consideration in all parallel cases by all other departments of the Government. ... At the same time, the candid citizen must confess that if the policy of the Government upon vital questions affecting the whole people is to be irrevocably fixed by decisions of the Supreme Court, the instant they are made in ordinary litigation between parties in personal actions the people will have ceased to be their own rulers, having to that extent practically resigned their Government into the hands of that eminent tribunal. ${ }^{59}$

Proponents of routine presidential non-enforcement also offer hypotheticals and historical examples in which the need for a presidential post-enactment check seems compelling and the President's constitutional obligation clear. ${ }^{60}$ Judge Easterbrook, for example, posited a statute that would require the President to execute the chief executive officer of a particular corporation and both dispossess his heirs and make them ineligible to hold public office. ${ }^{61}$ President Andrew Johnson's counsel made the following argument before the Senate defending President Johnson against conviction on the articles of impeachment:

If a law be declared by the Supreme Court unconstitutional he should not execute it.

If the law be upon its very face in flat contradiction to plain express provisions of the

Constitution, as if a law should forbid the President to grant a pardon in any case, or if a law should declare that he should not be commander-in-chief, or if a law should declare that he should take no part in the making of a treaty, I say the President, without going to the Supreme Court of the United States, maintaining the integrity of his department, which for the time being is intrusted to him, is bound to execute no such legislation; and he is cowardly and untrue to the responsibilities of his position if he should execute it. ${ }^{62}$

Moreover, his counsel argued, if President Johnson had complied with the unconstitutional construction of the law at issue in his impeachment, no one would have had standing to challenge it, and the constitutional violation would have gone unchecked. ${ }^{63}$

When faced with a parade of horribles, some proponents of mandatory enforcement remain unshaken. Westel Willoughby, for example, considered the argument that, in the absence of presidential non-enforcement authority, "a partisan statute passed over [the President's] veto can rob him of the right to be commander-in-chief, ${ }^{, 64}$ and responded as follows:

That there is danger that Congress may by a chance majority, or through the influence

59. Abraham Lincoln, First Inaugural Address (Mar. 4, 1861), in 6 A CompILATION OF THE MESSAGES AND PAPERS OF THE PRESIDENTS 1789-1897, at 9 (James D. Richardson ed., 1900).

60. Chief Justice Marshall similarly suggested hypothetical statutes that clearly would violate the Constitution in his defense of the authority of the federal courts to review the constitutionality of congressional statutes. See Marbury v. Madison, 5 U.S. (1 Cranch) 137, 177 (1803).

61. See Easterbrook, supra note 45, at 922.

62. 2 Trial of Andrew Johnson, President of the United States, Before the Senate of THE United STATES, ON IMPEACHMENT By THE HOUSE OF REPRESENTATIVES FOR High CRIMES AND MISDEMEANORS 200 (1868).

63. See id. at 208. President Johnson argued not only that he possessed the constitutional authority to refuse to comply with the statute to allow the courts an opportunity to review its constitutionality, but also that he had not, in fact, violated the statute, properly interpreted. See id. at 193-97.

64. WilloughBY, supra note 35, at 1503 (quoting Am. L. Rev., XXIII, 375). 
of sudden great passion, legislate unwisely or unconstitutionally, was foreseen by those who framed our form of government, and the provision was drawn that the President might at his discretion use a veto, but this was the entire extent to which he was allowed to go in the exercise of a check upon the legislation. ${ }^{65}$

Other commentators allow for exceptions, but only as necessary evils and without adequately reconciling the exceptions with their general view that the faithful execution of the laws requires execution of the laws as enacted. ${ }^{66}$

III

\section{REORIENTING THE DEBATE}

The largely dichotomous nature of the current academic debate may result in part from the manner in which the issue has been framed. Much of the debate has centered on resolving, in the abstract and as a general matter, whether the President possesses the authority to refuse to enforce unconstitutional laws, rather than exploring how the President best meets his Take Care obligation when, in his view, a particular statute and the Constitution conflict. To seek a unitary answer may skew the debate toward an unequivocal "yes," in part because compelling circumstances can be hypothesized in which the only way great harm could be averted would be for the President to refuse to enforce an unconstitutional statute.

Neither of the approaches most prevalent in the academic literature adequately describes the President's constitutional obligation when confronted with a constitutionally questionable statute. The President does not most faithfully execute the laws either by invariably refusing to enforce statutes based solely on his independent views of what the Constitution means or by enforcing all statutes regardless of their constitutional infirmities. Rather, whether the President best preserves the Constitution by declining to enforce a statute depends on the particular law at issue.

\section{A. Executive Branch Practice and Policy}

Presidents and their Departments of Justice have alternated between statements that seem to endorse routine non-enforcement ${ }^{67}$ and a context-

65. $I d$.

66. Professor May, for example, suggests that non-enforcement might be consistent with the Constitution in the following narrow circumstances:

If the Executive does possess a limited right of noncompliance, to be invoked properly four principles would have to be satisfied. First, the unconstitutionality of the law must be clearly indicated from the text of the Constitution, the intent of the Framers, or prior rulings of the Supreme Court. Second, the President must have exhausted all avenues for redressing the problem through the legislative process. Third, defiance of the law must for all practical purposes be the only way to bring the question of its constitutionality before the courts. And fourth, the Executive must take all possible steps to assure that judicial review actually occurs. Without these safeguards, the narrow privilege of noncompliance could easily become a modern equivalent of the suspending power.

May, supra note 21, at 988.

67. See, e.g., 1990 Barr Memorandum, supra note 38; 1992 Flanigan Memorandum, supra note 38. 
dependent approach ${ }^{68}$ to constitutionally objectionable laws. Although the executive branch at times has claimed expansive presidential non-enforcement authority, actual presidential practice has been far more restrained. Routine non-enforcement would represent a dramatic change from long-standing presidential practice. Congress has enacted numerous statutory provisions of questionable constitutionality, typically with the expectation that the President would enforce them, and Presidents have enforced the overwhelming majority of constitutionally objectionable laws, reserving non-enforcement for exceptional circumstances. ${ }^{69}$

The best formulations of a context-dependent approach to nonenforcement, and the formulations most consistent with past presidential practice, are found in a 1980 letter from Attorney General Benjamin Civiletti to a U.S. Senator ${ }^{70}$ and a 1994 letter from Assistant Attorney General Walter Dellinger to the Counsel to the President. ${ }^{71}$ Attorney General Civiletti described the President's non-enforcement authority as extremely limited. Civiletti stated that when the President is confronted with a constitutionally objectionable statute, "it is almost always the case that he can best discharge the responsibilities of his office by defending and enforcing the Act of Congress." 2 Civiletti identified just two circumstances in which the President should decline to enforce a law: first, when a statute is transparently invalid ${ }^{73}$ and, second, when a statute infringes on presidential power. ${ }^{74}$ Civiletti described this same standard as appropriate for decisions to decline to defend statutes against constitutional challenge in litigation. Civiletti's analysis, though not extensive, relied on the constitutional structure: "[T]he Executive can rarely defy an Act of Congress without upsetting the equilibrium established within our constitutional system; but if that equilibrium has already been placed in jeopardy by the Act of Congress itself, the case is much more likely to fall within that narrow class." 75

Assistant Attorney General Dellinger similarly stated that the President's "decision about whether or not to comply with" a constitutionally objectionable provision "is necessarily specific to context," enforcement appropriate in a broader range of contexts than would Attorney General Civiletti. Under Dellinger's formulation, whether the President should 20.

68. See, e.g., 1980 Civiletti Memorandum, supra note 20; 1994 Dellinger Memorandum, supra note

69. See generally May, supra note 21, at 904-86 (attempting to describe all instances of presidential non-enforcement between 1789 and 1981).

70. 1980 Civiletti Memorandum, supra note 20.

71. 1994 Dellinger Memorandum, supra note 20.

72. 1980 Civiletti Memorandum, supra note 20, at 55.

73. See id. at 63 n.1 ("If an Act of Congress directs or authorizes the Executive to take action which is 'transparently invalid' when viewed in light of established constitutional law, I believe it is the Executive's constitutional duty to decline to execute that power.").

74. See id. at 56-57.

75. Id. at 56 .

76. 1994 Dellinger Memorandum, supra note 20, at 200. 
enforce a particular statute that he considers unconstitutional depends largely on a prediction of how the Supreme Court would rule on the constitutionality of the provision in question. That is, the President typically has the authority to decline to enforce a statute if he determines both that a law is unconstitutional and that it is probable that the Court would agree. ${ }^{77}$ By contrast, if the President believes the Court would uphold the law, he generally should comply with the law. ${ }^{78}$ When the President's own powers are threatened, he has greater authority: The President may decline to enforce a statute unless he is convinced that the Court would disagree with his assessment. ${ }^{79}$ Dellinger also identified several other factors the President should consider in deciding whether to exercise non-enforcement authority, such as the likely effect of nonenforcement on the justiciability of the law and on the constitutional rights of affected individuals. ${ }^{80}$

Presidential non-enforcement is one of at least several areas of constitutional law in which academic scholarship could benefit from a closer consideration of executive branch precedent. ${ }^{81}$ In a recent instructive example, Professor H. Jefferson Powell considered the "executive branch perspective" on constitutional issues in the areas of foreign affairs and national security, where the executive branch has a uniquely rich body of precedent. ${ }^{82}$ Although the executive branch perspective on presidential non-enforcement is not nearly as well developed and consistent as its foreign affairs jurisprudence, Professor Powell's assessment is descriptive also of the approaches to non-enforcement described by Attorney General Civiletti and Assistant Attorney General Dellinger:

What is distinctive about the executive branch perspective, so distinctive that it amounts to a premise of the entire approach, is its recognition that structural arguments about the Constitution's meaning- "claims that a particular principle or practical result is implicit in the structures of government and the relationships that are created by the Constitution among citizens and governments"-can generate conclusions that are as creditable as are conclusions based on the Constitution's text. ${ }^{83}$

Moreover, Professor Powell's description of the executive branch's constitutional views on foreign affairs-as "internally coherent, properly respectful of Congress's legitimate constitutional prerogatives, and consistent with both Supreme Court decisions and constitutional practice" ${ }^{\$ 4}$ - provides a worthy goal for the continued development of presidential non-enforcement policy.

77. See id.

78. See id.

79. See id. at 201.

80. See id.

81. See generally Symposium, Executive Branch Interpretation of the Law, 15 CARDOZO L. REV. 21 (1993).

82. See Powell, supra note 19.

83. Id. at 534 (quoting Philip BobBitT, CONSTITUTIONAL FATE 7 (1982)).

84. Id. at 529 . 


\section{B. The Nature of the President's Constitutional Obligation}

An approach to constitutionally objectionable statutes in keeping with our constitutional structure requires of the President occasionally difficult constitutional judgments, but not interpretive autonomy. The task of defining and enforcing non-enforcement policy belongs in practice largely to the President. The courts are unlikely to provide much guidance about the scope of presidential non-enforcement authority given barriers to justiciability, such as standing and political question doctrines. ${ }^{85}$ In some instances, though, courts may opine on the limited question of the constitutionality of a particular statute the President refused to enforce.

The executive branch has claimed, to the contrary, that the Supreme Court all but resolved the legitimacy of presidential non-enforcement in 1926 in Myers v. United States. ${ }^{86}$ Myers arose when President Woodrow Wilson fired a postmaster without obtaining Senate approval as was required by statute. The Myers Court, faced with the same issue presented more than fifty years earlier in President Johnson's impeachment, held the provision unconstitutional. The Department of Justice has cited Myers as implicitly concluding that a President need not comply with a constitutionally objectionable statute, because the Court did not suggest that President Wilson had acted improperly by violating the statute prior to a judicial determination that the statute was unconstitutional. $^{87}$ But Myers may suggest only that, if presented with an instance of presidential non-enforcement, the Court will limit its review to the constitutionality of the statute at issue, and not consider whether the President acted properly in declining enforcement prior to a judicial ruling.

That a President may have the raw power to disregard constitutionally objectionable laws without risk of an adverse judicial response does not, of

85. Justice Jackson's observation regarding "the poverty of really useful and unambiguous authority applicable to concrete problems of executive power as they actually present themselves" describes well the paucity of judicial precedent relevant to presidential non-enforcement. Youngstown Sheet \& Tube Co. v. Sawyer, 343 U.S. 579, 634 (1952).

86. 272 U.S. 52 (1926).

87. The Department of Justice has gone as far as to state the following:

Myers holds that the President's constitutional duty does not require him to execute unconstitutional statutes; nor does it require him to execute them provisionally, against the day that they are declared unconstitutional by the courts. He cannot be required by statute to retain postmasters against his will unless and until a court says that he may lawfully let them go. If the statute is unconstitutional, it is unconstitutional from the start.

1980 Civiletti Memorandum, supra note 20, at 59; see also 1994 Dellinger Memorandum, supra note 20, at 201 (describing Myers as "implicitly vindicat[ing]" presidential non-enforcement authority). The executive branch also has cited Justice Scalia's concurrence, joined by three other Justices, in Freytag $v$. Commissioner, in which he states, in passing and without elaboration, that the President has "the power to veto encroaching laws ... or even to disregard them when they are unconstitutional." See 1994 Dellinger Memorandum, supra note 20, at 199 (citing Freytag v. Commissioner, 501 U.S. 868, 906 (1991)). Finally, the executive branch has relied on Justice Jackson's concurrence in Youngstown, 343 U.S. 579, as recognizing the existence of presidential authority to act contrary to a statutory command. See id. Youngstown does provide support for a context-dependent approach to non-enforcement, as is well explored by Professors Barron and Strauss. See David Barron, Constitutionalism in the Shadow of Doctrine: The President's Non-Enforcement Power, 63 Law \& Contemp. Probs. 61, 92-95 (Winter/ Spring 2000); Strauss, supra note 15, at 118-19. 
course, resolve whether the presidential action was proper. ${ }^{88}$ The President's obligation faithfully to execute the law is not contingent on the availability of judicial review as a check on presidential excess. Indeed, the President should act with particular care when a controversial assertion of authority may be nonjusticiable.

Even when judicial review is unavailable, Congress possesses some ability to inform presidential non-enforcement policy. The President and Congress are appropriately engaged in an ongoing dialogue about the existence and parameters of the President's authority. Presidents and their legal advisers long have struggled with the dilemma, both to resolve how to address particular constitutionally objectionable laws and to develop more general guidelines to govern non-enforcement decisions. Congress, for its part, has scrutinized particular instances in which Presidents have refused to enforce statutory provisions, the most famous instance of which resulted in the impeachment of President Johnson for refusing to comply with the Tenure in Office Act. ${ }^{89}$ Congress also has enacted laws that require the Attorney General to notify Congress if the Department of Justice determines that it will not enforce a provision of law because the Department believes the provision is not constitutional..$^{90}$

The Constitution does not provide clear answers regarding presidential nonenforcement. Whether the President has exceeded his constitutional authority by refusing to enforce any particular statute may be open to reasonable disagreement. A President's overall policy or practice regarding the circumstances under which the President will decline to enforce constitutionally objectionable laws may be more susceptible to evaluation than an individual non-enforcement decision, though there, too, the Constitution does not mandate a precise set of relevant factors.

The Constitution is clear, though, in its mandate that the President ensure

88. To the extent Myers can be read to provide any support for presidential non-enforcement, that support must be limited to analogous cases - namely, when a statute encroaches on executive power and judicial review is all but impossible unless the President violates the statute. Myers does not support sweeping presidential authority to violate any law the President believes is unconstitutional.

89. See also Constitutionality of GAO's Bid Protest Function: Hearings Before the Subcomm. on Legislation and Nat'l Security of the House Comm. on Gov't Operations, 99th Cong. (1985) (examining the decision not to enforce provisions of the Competition in Contracting Act) [hereinafter Hearings]; H.R. Rep. No. 99-138 (1985) (same); Department of Justice Authorization and Oversight: Hearings Before the Comm. on the Judiciary, 96th Cong. 853-908 (1980) (examining the decision not to defend section 399(a) of the Public Broadcasting Act of 1967 and standards to govern decisions not to enforce or defend federal statutes); Representation of Congress and Congressional Interests in Court: Hearings Before the Subcomm. on Separation of Powers of the Senate Comm. on the Judiciary (1975-76) (examining constitutional and policy issues raised by the executive branch's defense of the constitutionality of federal statutes).

90. See, e.g., Department of Justice Appropriations Act, Fiscal Year 1980, Pub. L. No. 96-132, § 21, 93 Stat. 1040, 1049-50 (1979). This law also requires the Department of Justice to notify Congress if it intends not to defend a provision of law against constitutional challenge. See id. Subsequent appropriations statutes have provided that these notification requirements shall remain in effect. See, e.g., Consolidated Appropriations Act, 2000, Pub. L. No. 106-113, §102, 113 Stat. 1501, 1501A-19 (1999). 
that the laws are faithfully executed. The Take Care Clause is phrased as a command, not a grant of authority, and suggests no gap between constitutional obligation and aspiration. It is not properly interpreted, for example, as requiring the President to be only minimally faithful in his execution of the laws, while creating the aspiration that he will be exceptionally faithful. The lack of constitutional clarity and judicial oversight does not transform the President's Take Care obligation into a presidential authority to be exercised at the President's discretion.

How, then, does the President take care that the laws are faithfully executed when confronted with constitutionally objectionable laws? The purpose and general effect of the Take Care Clause is not in dispute. The President clearly may not, at his discretion, dispense with laws enacted by Congress and execute laws selectively. ${ }^{91}$ What is the significance, then, when the basis for a refusal to enforce the law is not presidential policy preference, but the President's belief that the statute is unconstitutional? It is no answer to say that the Constitution, and not the President, dispenses with an unconstitutional law. To be more precise, it is the President's interpretation of the Constitution that dispenses with the law when he refuses to enforce it. The critical question is when the President's constitutional judgment should govern whether statutes are enforced. The indeterminate text of the Take Care Clause must take its meaning from the constitutional structure. Indeed, even if the Framers had not included the Take Care Clause in the Constitution, the obligation that it imposes on the President would have been implicit in the constitutional structure, which still would have supported a context-dependent approach to presidential non-enforcement.

Proponents of routine non-enforcement of constitutionally objectionable laws provide a useful starting point in emphasizing that " [i]t is emphatically the province and duty' of the executive department, no less than the judiciary, 'to say what the law is." ${ }^{\prime 92}$ As the head of a coordinate branch of the government, the President, no less than the courts, possesses the implicit constitutional authority and responsibility to interpret the Constitution in carrying out his assigned functions. As the Supreme Court stated in United States v. Nixon, "[i]n the performance of assigned constitutional duties each branch of the Government must initially interpret the Constitution, and the interpretation of its powers by any branch is due great respect from the others." ${ }^{93}$ In some areas, such as foreign affairs and war powers, the executive may constitute the primary source of interpretation, with little or no relevant judicial precedent or likelihood of judicial review and only the threat of congressional oversight and

91. See Kendall v. United States ex rel. Stokes, 37 U.S. (12 Pet.) 524, 613 (1838).

92. Paulsen, supra note 23, at 221 (quoting Marbury v. Madison, 5 U.S. (1 Cranch) 137, 177 (1803)); see also Lawson \& Moore, supra note 47, at 1268 (similarly paraphrasing Marbury).

93. 418 U.S. 683, 703 (1974). The Court went on to conclude, however, that it had jurisdiction to review the constitutionality of the President's assertion of executive privilege: "[I]t is the province and duty of this Court 'to say what the law is' with respect to the claim of privilege presented in this case." Id. at 705 (quoting Marbury, 5 U.S. at 177). 
possible impeachment to operate as governmental checks on the President. ${ }^{94}$ The obligation to interpret and uphold the Constitution extends as well to the obligation faithfully to execute the laws. The President must consider the constitutionality of statutes to enforce them, if only to engage in the uncontroversial practice of construing them when possible in a manner that avoids constitutional problems. ${ }^{95}$

A critical related question is how the President should go about the necessary task of constitutional interpretation. An extensive body of academic commentary considers the political branches' roles in interpreting the Constitution and, in particular, what deference they owe, or, as a prudential matter, should give, to judicial interpretations. ${ }^{96}$ Proponents of routine nonenforcement also advance the debate by emphasizing that the President appropriately plays a role in the determination of constitutional meaning and that the quality of constitutional interpretation benefits from the involvement of the political branches in the interpretive process. Though the precise contours vary, broad support exists among academic commentators for the authority of the political branches in at least some circumstances to act on their own views of what the Constitution requires, and not just to apply judicial precedent and predict judicial outcomes. ${ }^{97}$ Most commentators agree, for example, that the President appropriately may veto a bill or grant a pardon based on a view of the Constitution that the Supreme Court has rejected. ${ }^{98}$

The assertion of independent executive interpretive authority in the context of presidential non-enforcement of statutes, however, raises constitutional difficulties. The analogy between judicial review and executive review of the constitutionality of laws is not as apt as some have argued. Most important, the Constitution commands the President-and not the judiciary-to ensure the faithful execution of the laws, and sets forth the President's role in determining the content of the laws he is to execute.

Proponents of routine non-enforcement focus on the separate and independent nature of the coordinate branches of government-in particular, on the President's status as the head of a coordinate branch charged with the execution of the laws-to the exclusion of the relationships between the branches that the Constitution establishes. ${ }^{99}$ They interpret the Take Care

94. See Powell, supra note 19 , at 529 (arguing that "the Constitution is best read to vest the President with primary constitutional authority over the conduct of foreign affairs and the protection of national security").

95. "When the validity of an act of the Congress is drawn in question, and even if a serious doubt of constitutionality is raised, it is a cardinal principle that this Court will first ascertain whether a construction of the statute is fairly possible by which the question may be avoided." Ashwander v. Tennessee Valley Auth., 297 U.S. 288, 348 (1936) (Brandeis, J., concurring) (quoting Crowell v. Benson, 285 U.S. 22, 62 (1932)), cited in Jones v. United States, 120 S. Ct. 1904, 1911 (2000).

96. See, e.g., sources cited infra notes $118,122,125 \& 127$.

97. Despite significant consensus at the level of theory, the U.S. legal system, including our system of legal education, at present promotes a version of judicial supremacy that denigrates the role of the political branches in interpreting the Constitution. See infra note 123.

98. See, e.g., supra text accompanying notes 55-59.

99. As Professor David Strauss has noted, commentators tend to conflate two questions: one, how 
Clause as imposing no constraints on the President's independent interpretive authority. ${ }^{100}$ "Faithful" execution of the laws connotes execution in conformity with the Constitution, they argue, and the President need not defer to constitutional judgments of Congress or the courts that the President believes wrong. Rather, to execute the laws faithfully, the President may (or must) engage in an independent review of the constitutionality of all laws and decline to enforce those he believes are unconstitutional. This view rests on a skewed interpretation of the President's "Take Care" obligation to reinforce executive independence, as though the only fidelity owed by the President is to his own constitutional views regarding the statute at issue. The Take Care Clause, however, was aimed at clarifying constraints on presidential power, and the President must be faithful as well to the Constitution's structure, its allocation of powers, and the processes that advance the determination of constitutional meaning.

\section{Two Guiding Principles}

The constitutional structure suggests that Presidents confronted with constitutionally objectionable laws should be guided by two principles. First, the President must enforce the laws in a manner that preserves and respects the integrity of the lawmaking process as set forth in Article I, including the roles Article I assigns the President and Congress in determining the content and ensuring the constitutionality of laws. Second, the President's non-enforcement decisions must promote not the President's own constitutional views in isolation, but the Constitution itself, which in turn depends upon principled constitutional interpretation by all three branches and a recognition of the judiciary's special role in that process. Application of these two principles reveals the constitutional shortcomings of routine non-enforcement and suggests when non-enforcement is appropriate.

1. Preserve and Respect the Legislative Process. The scope of the President's non-enforcement authority must not be defined so broadly as to undermine the

the President should go about the task of interpreting the Constitution in exercising his constitutional authorities, and two, whether the President may refuse to enforce a law he believes to be unconstitutional. Strauss correctly cautioned that the latter question, "raises another difficult... question of constitutional law, about the substantive requirements of the Take Care Clause of the Constitution." David A. Strauss, Presidential Interpretation of the Constitution, 15 CARDOZO L. REV. 113, 117 (1993). As Strauss acknowledged, "[t]he two questions are related; the concerns they raise about the President's role in the constitutional scheme are roughly similar." Id. at 117. What faithful execution of the laws means in the context of a law the President believes is unconstitutional must be considered in light of the constitutional structure and, in particular, the allocation of powers in the process of lawmaking.

100. According to Professor Paulsen, for example, "“[f]aithful' execution of the laws implies execution in accordance with a proper legal interpretation of those laws and applicable constitutional principles.... It demands full legal review of all matters that come before [the President] to be 'faithfully executed'; that is, executive review of the legal correctness of other branches' actions, including questions of ordinary statutory interpretation." Paulsen, supra note 23, at 261-62 (emphasis added). 
lawmaking process, including Congress's core legislative function. ${ }^{101}$ The Constitution, of course, expressly allocates lawmaking powers among the branches and defines the role of the executive in determining the content of legislation. ${ }^{102}$ The Framers crafted what the Supreme Court has described as a "single, finely wrought and exhaustively considered, procedure" for enacting legislation, ${ }^{103}$ which concludes with Congress's power to say finally by a twothirds vote whether a bill the President views as unconstitutional nonetheless will become law. A presidential refusal to enforce a law should not be viewed, as some have argued, as invariably and directly violative of Article I's prescribed process for lawmaking. The President's decision not to enforce a law occurs after the lawmaking process is complete and is properly viewed as an exercise of executive, not legislative, power. ${ }^{104}$ Nonetheless, in many circumstances presidential non-enforcement would be inconsistent with the constitutional structure.

The lawmaking process allows the President significant, uncontroversial methods of promoting the constitutionality of the laws. The President may, and should, evaluate proposed legislation for constitutionality, work with Congress to cure any defects, veto bills when Congress has been unresponsive, and even after enactment, urge Congress to repeal unconstitutional provisions. During this process, the President's constitutional views need not be limited to existing

101. This inquiry is similar to formulations used by the Supreme Court to determine whether a law violates the general principle of the constitutional separation of powers. See Morrison v. Olson, 487 U.S. 654, 696 (1988) ("[T]hese features of the Act ... ensure that the President is able to perform his constitutionally assigned duties."); Community Futures Trading Comm'n v. Schor, 478 U.S. 833, 856-57 (1986) ("[T]he separation of powers question presented in this litigation is whether Congress impermissibly undermined ... the role of the Judicial Branch."); Nixon v. Adm'r of Gen. Servs., 433 U.S. 425, 443 (1977) ("[I]n determining whether [an] Act disrupts the proper balance between the coordinate branches, the proper inquiry focuses on the extent to which it prevents the Executive Branch from accomplishing its constitutionally assigned functions."); see also The Constitutional Separation of Powers Between the President and Congress 10-14 (May 7, 1996) (memorandum by Assistant Attorney General Walter Dellinger) [hereinafter 1996 Dellinger Memorandum], available in 1996 WL 876050 (OLC).

102. See U.S. CONST. art. I, § 7, cl. 2.

103. Immigration \& Naturalization Serv. v. Chadha, 462 U.S. 919, 951 (1983).

104. Support for the contrary view may be claimed in the Supreme Court's opinion in Clinton $v$. New York, in which the Court invalidated what is commonly described as the Line Item Veto Act. See 524 U.S. 417 (1998). As discussed above, advocates of what I have termed mandatory enforcement have likened presidential non-enforcement to an absolute presidential line-item veto power. See supra text accompanying notes 27-35.

The Court in Clinton held that Congress could not by statute confer on the President the power to "cancel" certain statutory provisions that provided for new spending because such a cancellation "[i]n both legal and practical effect" constituted a statutory repeal that failed to comply, as it must, with the requirements of Article I. 524 U.S. at 438. The Court's willingness to invalidate the power to "cancel" items as "the functional equivalent" of a repeal, $i d$. at 444 , arguably may suggest that the Court would view presidential non-enforcement of a constitutionally objectionable statutory provision as the functional equivalent of an absolute line-item veto and therefore similarly violative of Article I. Whether or not the Court's analysis in Clinton is persuasive, it is distinguishable. Presidential nonenforcement does not involve an attempt by Congress to confer by statute new powers on the President, but a question of the Constitution's initial allocation of authorities and responsibilities among the branches and in particular the President's Article II enforcement obligations when he believes that enforcement of a statute would violate the Constitution. 
precedent and predictions of how courts would rule. Moreover, the President's power to execute the laws includes the authority, comparable to that of a court, to interpret provisions that raise serious constitutional difficulties so as to avoid the constitutional problems. These methods of promoting constitutional supremacy and dialogue between Congress and the President, in ways entirely consistent with the constitutional structure, would be undermined if Presidents routinely disregarded laws they viewed as unconstitutional.

The aspect of the lawmaking process most significant for defining when presidential non-enforcement is constitutionally appropriate is the nature of the presidential veto. Article I allows Congress to override even a constitutionally based veto and to enact legislation that the President has notified Congress he believes is unconstitutional. ${ }^{105}$ The Framers carefully considered how to define this revisionary power, ultimately rejecting an absolute presidential veto and also reducing from the three-fourths originally proposed to two-thirds the majority needed to enact a law to which the President had objected. ${ }^{106}$ The Framers contemplated that the President would use the power to return a bill when confronted with unconstitutional legislation, and in particular legislation threatening presidential power. ${ }^{107}$ From the earliest days of our constitutional government, Presidents in practice often have vetoed legislation on constitutional grounds; President George Washington's first veto was constitutionally based. ${ }^{108}$ While the Framers gave the President the veto power in order to protect the presidency from congressional encroachments, they also required the President to notify Congress of the basis for his objections and gave Congress the ultimate power to reject the President's views.

If Presidents routinely were to disregard constitutionally objectionable laws, they would seriously distort this lawmaking process. Congress's lawmaking function, though formally intact, would be substantially impaired. Most significant would be the effect on Congress's authority to override a presidential

105. The Constitution states:

If he approve he shall sign it, but if not he shall return it, with his Objections to that House in which it shall have originated, who shall enter the Objections at large on their Journal, and proceed to reconsider it. If after such Reconsideration two thirds of that House shall agree to pass the Bill, it shall be sent, together with the Objections, to the other House, by which it shall likewise be reconsidered, and if approved by two thirds of that House, it shall become a Law.

U.S. CONST. art. I, $\S 7$.

106. See 2 The Records of THE Federal Convention of 1787, at 585-87 (Max Farrand ed., 1966) [hereinafter THE CONVENTION RECORDS]. For a thorough discussion of the history of the Veto Clause as it relates to presidential non-enforcement, see May, supra note 21, at 876-81.

107. Elbridge Gerry noted at the Constitutional Convention, "The primary object of the revisionary check in the President is not to protect the general interest, but to defend his own department." 2 THE CONVENTION RECORDS, supra note 106, at 586; see also THE FEDERALIST No. 73, at 373 (Alexander Hamilton) (Garry Wills ed., 1982) ("The primary inducement to conferring the power in question upon the executive, is to enable him to defend himself ....").

108. President Washington vetoed a bill that sought to apportion to the states representation in the House of Representatives in a manner inconsistent with the constitutionally prescribed apportionment. See EDWARD CAMPBEll MASON, THE VETO POWER: ITS ORIGIN, DEVELOPMENT AND FUNCTION IN THE GOVERNMENT OF THE UNITED STATES (1789-1889) 25-27, 129-30 (1890). 
veto. The President could either sign into law an unconstitutional provision and then decline to enforce it, thereby depriving Congress of the opportunity to override a constitutionally based veto, or veto the bill and, if Congress overrides the veto, refuse to enforce the provision. Either course would thwart Congress's will as expressed in the law and greatly diminish Congress's ability to promote its constitutional views. Opponents of presidential authority sometimes overstate this case. Professor May, for example, says that to recognize presidential non-enforcement authority "would effectively render Article I's qualification of the veto meaningless." 109 Congress's ability to override presidential vetoes often still would have significance. In particular, whenever a President returned a bill because of policy, rather than constitutional, objections, he would continue to be bound to enforce the law if passed by a two-thirds majority. But routine non-enforcement of constitutionally objectionable laws would substantially negate Congress's power to override a presidential veto based on constitutional objections, a specific category of cases in which the Framers expected the veto would be used.

Routine non-enforcement also would distort the process of lawmaking by creating disincentives for the President to use his veto power and incentives to sign unconstitutional laws. A President would have less need to veto otherwisedesirable legislation that contained a constitutionally objectionable provision if he were free to sign the law and simply disregard the unconstitutional portion. A President also would have less incentive to work with Congress to identify and correct constitutional defects prior to enactment, or to work for repeal or amendments after enactment. The number of unconstitutional enactments with unenforced provisions could be expected to escalate. A one-way ratchet effect likely would develop under which Presidents would rely on non-enforcement for any provision that is similar to one that previously was the subject of presidential non-enforcement, rather than undertake the often difficult and politically costly task of working to correct the provision through the lawmaking process.

To fulfill his constitutional responsibilities, the President must consider not only the best constitutional outcome for each constitutionally objectionable statute, assessed individually, but also the constitutionality of our laws in the aggregate, including the ways in which non-enforcement encourages the enactment of unconstitutional laws. Moreover, non-enforcement of an unconstitutional law does not as fully protect against constitutional harm as a veto or other action to prevent the law's enactment. A law unenforced by the President remains on the books, so to speak, and the public is denied clear notice about the legal requirements to which they are subject. The unenforced law may continue to have effect, including, in some cases, enforcement by others, consideration by the courts in interpreting other laws, or effects on private acts, and a subsequent President could decide to enforce the law. ${ }^{110}$ Our

109. May, supra note 21, at 881.

110. See Rappaport, supra note 52, at 774 . 
constitutional system is served far better when the enactment of an unconstitutional law is prevented, than when the President unilaterally declines to enforce a law after enactment.

If Presidents consistently vetoed all legislation they considered unconstitutional, the dilemma of constitutionally objectionable statutes would arise far less often-primarily when Congress has overridden a President's veto (for example, President Johnson's veto of the Tenure in Office Act) or when a President's views differ from those of a predecessor who signed the law. When presented with a free-standing provision that the President interprets to be unconstitutional, the President's oath of office is best interpreted as requiring a veto. There is no constitutional justification for the President to sign the bill and then refuse to enforce it.

The veto power is diminished and the President's constitutional obligation is complicated, however, by the congressional practice of combining numerous unrelated provisions into a single bill. The use of omnibus legislation often makes it impossible for Presidents to veto provisions they view as unconstitutional without sacrificing other unobjectionable and important provisions (for example, President Clinton's decision to sign the Defense Authorization Act containing the HIV provision). A veto of omnibus legislation could jeopardize vital national interests. The Lend Lease Act provides a compelling example. ${ }^{111}$ President Franklin Roosevelt signed the Act despite his personal belief that one of its provisions, which authorized Congress by concurrent resolution to rescind specified authorities granted to the President, was unconstitutional, because he believed the Act vital to the success of the allies in World War II. ${ }^{112}$ When a bill with multiple provisions includes an unconstitutional provision, the executive branch's long-held position seems the better view: The Constitution does not invariably demand a veto. ${ }^{113}$

Omnibus bills present members of Congress with a similar dilemma. The

111. See Robert H. Jackson, A Presidential Legal Opinion, 66 HARV. L. REV. 1353, 1354-57 (1953).

112. President Roosevelt was sufficiently troubled by the provision that he asked then-Attorney General Robert H. Jackson (who, interestingly, did not fully agree with the President's objections) to memorialize the President's views in a legal memorandum. See id. at 1357-58. The U.S. Supreme Court later agreed with President Roosevelt's constitutional assessment. See Chadha, 462 U.S. at 94459.

113. See 1994 Dellinger Memorandum, supra note 20, at 202-03; Signing Statements Memorandum, supra note 14, at 134-35. Professor Rappaport argues, to the contrary, that, at a minimum, the President must veto any bill that contains a constitutionally objectionable provision he intends not to enforce: "[A] constitutional obligation strong enough to justify and require non-enforcement would also require a veto." Rappaport, supra note 52, at 771. To the argument that Presidents sometimes need to sign legislation that contains unconstitutional provisions because of other important provisions in the bill, Rappaport responds, "[t]he President's legal obligation to disapprove an unconstitutional bill ... takes precedence over policy justifications." Id. at 776 .

While I believe that the President is not invariably obligated to veto a bill before refusing to enforce it, the President is constitutionally obligated, before resorting to non-enforcement, first seriously to explore less restrictive alternatives, including seeking corrections in legislation before passage, interpreting constitutionally objectionable provisions to avoid constitutional problems, and considering the possibility of a veto. As a matter of practice, the executive branch routinely reviews pending legislation for constitutional defects and typically notifies Congress of its constitutional objections. 
courts afford acts of Congress a presumption of constitutionality in part in recognition of Congress's obligation to uphold the Constitution through its enactments. ${ }^{114}$ However, as commentators have recognized, ${ }^{115}$ congressional passage of a bill does not in reality guarantee that members of Congress actually considered the constitutionality of each of the bill's provisions, let alone reached a considered judgment in its favor. Even when members of Congress do wrestle with the constitutionality of a bill, they often will not vote against a bill containing numerous desirable provisions on the basis of a single unconstitutional provision, just as Presidents often will not veto such a bill. In other cases, members of Congress will not even be aware of the existence of the provision, when, for example, the provision is one of many and was added late in the legislative process. What, then, is the obligation of a legislator when an unconstitutional provision is a relatively small part of a bill containing critically important provisions? The obligations of members of Congress are best viewed as analogous to those of the President: They need not vote against every bill that contains an unconstitutional provision.

Not infrequently, however, Congress passes and Presidents sign bills that include constitutionally objectionable provisions without a strong justification, which in at least some circumstances seems in derogation of their oath and responsibility to uphold the Constitution in the exercise of their constitutional functions. Presidential vetoes, for example, rarely risk results as momentous as might have followed from a veto of the Lend Lease Act. The elevation of specific policy objectives over constitutional principles comes at a high cost: the erosion of the constitutionally prescribed means of preventing the enactment of unconstitutional laws. This harm is not merely some abstract loss. The American people are subjected to unconstitutional laws and the very structure of our government, designed to protect individual liberties, is undermined. ${ }^{116}$

Although consideration of this first principle-preservation of the

114. See, e.g., City of Boerne v. Flores, 521 U.S. 507, 535 (1997).

115. See, e.g., Paul Brest, The Conscientious Legislator's Guide to Constitutional Interpretation, 27 STAN. L. REV. 585, 587-89 (1975); Harrison, supra note 47, at 359-61 (arguing that the Constitution does not impose a general obligation on members of Congress to consider the constitutionality of pending legislation).

116. At least one President and several commentators have suggested that the President may possess inherent line-item veto authority even in the absence of a grant of authority or, at a minimum, the authority to line-item veto provisions in a bill that are unconstitutional. See generally J. Gregory Sidak \& Thomas A. Smith, Four Faces of the Item Veto: A Reply to Tribe and Kurland, 84 Nw. U. L. REV. 437 (1990). Unlike when the President refuses to enforce a provision, Congress would retain the power to override the veto. Others have responded that the Framers were conscious of the possibility that Congress would bundle unrelated provisions in a single bill and chose not to preclude bundling. The colonial legislatures, as well as the First Congress, engaged in this practice, though on a much smaller scale than currently occurs. See 135 CONG. REC. S26,608-09 (1989) (memorandum from Prof. Tribe and Prof. Kurland to Sen. Kennedy); Paul R.Q. Wolfson, Note, Is a Presidential Item Veto Constitutional?, 96 YALE L.J. 838, 840-41 (1987). Regardless of any diminished effectiveness of the veto as a check on unconstitutional enactments, Article I clearly precludes any inherent presidential authority to line-item veto provisions in a bill. See Rappaport, supra note 52; The President's Veto Power, 12 Op. Off. Legal Counsel 128 (1988) (memorandum by Assistant Attorney General Charles J. Cooper). 
lawmaking process as prescribed by Article I-precludes routine presidential non-enforcement, in limited circumstances the President would not significantly threaten the lawmaking process by declining to enforce a constitutionally objectionable law. The President should begin, as the courts do, with a presumption of constitutionality for laws enacted in conformity with Article I. From the perspective of the President's obligation, this presumption is better described as a presumption of enforceability.

In determining whether the presumption is overridden in a particular instance, among the factors the President should consider is whether and to what extent a refusal to enforce a statutory provision actually would negate congressional will: To what extent, if at all, did Congress actually consider the provision in question and its constitutionality? A presidential search for what influenced Congress - or, more accurately, members of Congress-to pass a bill will encounter many of the same difficulties that inform the Court's deferential stance in reviewing acts of Congress and the Court's reluctance to inquire, for example, into Congress's actual motive in passing a law. Nonetheless, evidence often will exist as to whether Congress or some of its members held a competing constitutional view, or even identified and considered the constitutional issue, and the President should view such evidence as relevant to his enforcement decision.

The most difficult circumstances for non-enforcement arise when Congress enacts a constitutionally objectionable provision as the only, or primary, provision in a bill, by a two-thirds majority over the President's constitutionally based veto. Non-enforcement is far less problematic when the provision is one of many in an omnibus bill, with no evidence that members of Congress considered its constitutionality. In the latter circumstance, it may be appropriate for the President to view his decision not to enforce the provision as a kind of conditional non-enforcement, based in part on Congress's inattention to the constitutional problem presented by the provision. If Congress subsequently were to consider the President's constitutional views and reenact the provision based on a differing interpretation, the constitutionally preferred response often would be for the President to enforce the reenacted provision.

In some cases, the harm to Congress's lawmaking function would be exacerbated by the effect of non-enforcement on the justiciability of the provision. In some instances, by refusing to implement a statute, the President would render the constitutionality of the law nonjusticiable; he would thereby prevent judicial review and deny Congress any ability to test its competing view of the law's constitutionality and seek enforcement of the law as enacted. In particular, if a President were to disregard a law he viewed as violative of individual rights, he might avoid any legally cognizable injury and thus eliminate the possibility that anyone with standing could litigate the constitutionality of the law. For example, if President Clinton had refused to comply with Congress's command that he discharge HIV-positive members of 
the military, constitutional challenge to either the statute or President Clinton's action likely would have been impossible. The President's disregard of the law would have denied Congress the opportunity to defend the provision in court and seek a judicial order directing the President to enforce it.

In other instances, by complying with a statute, the President virtually guarantees that it will never be challenged. This result is particularly likely for statutes that implicate presidential power and directly affect the presidency as an institution rather than any private individual. If Presidents had complied, for example, with unconstitutional restrictions on their authority to remove certain executive branch officers, such as the restriction at issue in President Johnson's impeachment, the Supreme Court likely would not have had occasion to declare the restrictions unconstitutional. Non-enforcement in such cases, though still potentially threatening to the constitutional process of lawmaking, is less troublesome because it at least creates the possibility for Congress to urge a court to uphold the law.

2. Promote the Constitution and the Determination of Constitutional Meaning. The second principle that should guide presidential non-enforcement decisions is premised on the Constitution's status as supreme law in the structure of our government and the President's obligation to uphold the Constitution in the exercise of his authority. Proponents of routine nonenforcement are right that the President's obligation to take care that the laws are faithfully executed requires consideration of what will promote the supremacy of the Constitution. But the President does not best promote the Constitution and the determination of what the Constitution requires by acting solely on his own constitutional views in deciding whether to enforce constitutionally objectionable laws. A superior approach requires the President to respect the "comparative institutional competencies" of the three branches of government $^{117}$ and to encourage dialogue among the branches about constitutional meaning. This entails not just consideration of, but deference to, the views of Congress and the Court.

As a general matter, the quality of constitutional interpretation benefits from the responsible involvement of all three branches in the interpretive process. The President, as the only nationally elected representative of the people, brings a valuable perspective to the debate over the Constitution's meaning. Professor Laurence Tribe has described the salutary effect of involving Congress and the President in an interpretive process regularly criticized as being anti-democratic:

Congress and the President must thus be recognized as having the power and the duty to interpret the document in a way that may command the respect of others. This argument is among the many answers to the charge that constitutional interpretation is a disturbingly anti-democratic enterprise. Although the Constitution in a sense stands beyond ordinary politics - and even beyond the Supreme Court's interpretations of the Constitution as text and as history-democracy is surely less

117. Eisgruber, supra note 53, at 348. 
threatened by a system of constitutional interpretation in which many may share significant and respected roles than by a system with but one authoritative voice. ${ }^{118}$

In practice, both the President and Congress at times fail-or decline- to exercise their lawmaking authorities to advance their constitutional views and the constitutionality of statutes. ${ }^{119}$ Even when presidential or congressional action reflects considered constitutional judgments, the courts sometimes fail adequately to consider those views. ${ }^{120}$ Despite these failings, the constitutional ideal, which non-enforcement policy should promote, remains a system that encourages all branches of government to take seriously their obligation to uphold the Constitution and affords appropriate respect to their constitutional judgments.

Central to determining the President's appropriate role in developing constitutional meaning is whether and to what extent the President should defer to the Supreme Court's interpretations. ${ }^{121}$ Some commentators argue for absolute deference to holdings of the Supreme Court, ${ }^{122}$ and the Court's own statements sometimes seem to endorse this strong form of judicial supremacy. ${ }^{123}$

118. Laurence H. Tribe, 1 American Constitutional Law 262 (3d ed. 2000). Professor Tribe also wrote,

[T] he Constitution remains in significant degree a democratic document-not only written, ratified and amended through essentially democratic processes but indeed open at any given time to competing interpretations limited only by the values which inform the Constitution's provisions themselves, and by the complex political processes that the Constitution createsprocesses which on various occasions give the Supreme Court, Congress, the President, or the states, the last word in constitutional debate.

Id. at 267. See generally id. at 254-67.

119. See discussion supra at notes 111-16 and accompanying text.

120. See infra note 123 .

121. For a useful discussion of various models of executive branch interpretation, see John O. McGinnis, Models of the Opinion Function of the Attorney General: A Normative, Descriptive, and Historical Prolegomenon, 15 CARDOZO L. REV. 375 (1993).

122. See Burt Neuborne, The Role of the Legislative and Executive Branches in Interpreting the Constitution, 73 CORNELL L. REV. 375, 377 (1988) ("[O]nce you have a narrow precedential holding in a case, there is a legal duty on the part of the organs of government to defer to the Supreme Court's reading of the Constitution."); see also Burt Neuborne, The Binding Quality of Supreme Court Precedent, 61 TUL. L. REV. 991, 1001 (1987).

123. Although the Court has acknowledged the authority and responsibility of the other branches to interpret the Constitution, it seems to reserve for itself interpretive primacy in at least many circumstances, without adequate consideration of the differing views of the political branches. For example, in City of Boerne v. Flores, the Court stated:

When Congress acts within its sphere of power and responsibilities, it has not just the right but the duty to make its own informed judgment on the meaning and force of the Constitution....

Were it otherwise, we would not afford Congress the presumption of validity its enactments now enjoy.

521 U.S. 507, 535 (1997). The Court went on to hold, however, that Congress cannot "decree the substance of the Fourteenth Amendment's restrictions on the States. ... It has been given the power 'to enforce,' not the power to determine what constitutes a constitutional violation." Id. at 519 . Similarly, the Court stated in Cooper v. Aaron:

Article VI of the Constitution makes the Constitution the "supreme Law of the Land." In 1803, Chief Justice Marshall, speaking for a unanimous Court, referring to the Constitution as "the fundamental and paramount law of the nation," declared in the notable case of Marbury $v$. Madison that "It is emphatically the province and duty of the judicial department to say what the law is." This decision declared the basic principle that the federal judiciary is supreme in the exposition of the law of the Constitution, and that principle has ever since 
Others argue, to the contrary, that the Constitution supports complete interpretive independence of the three branches of government within their spheres of constitutional authority. ${ }^{124}$ Some proponents of substantial, but not complete, presidential interpretive autonomy, including Professor Christopher Eisgruber and Professor David Strauss, argue for an intermediate position: While the relative competencies of the branches typically support presidential deference to judicial rulings, deference is not always warranted and in some cases the courts should defer to the expertise of Congress or the President. ${ }^{125}$ Significantly, the executive branch does not adhere to the position that would maximize presidential interpretive independence, but current policy instead typically mandates deference to applicable Supreme Court precedent:

[T] he constitutional structure obligates the executive branch to adhere to settled judicial doctrine that limits executive and legislative power. While the Supreme Court's decisions interpreting the Constitution cannot simply be equated with the Constitution, we are mindful of the special role of the courts in the interpretation of the law of the Constitution. ${ }^{126}$

While it is not my purpose here to engage in all aspects of the debate over the appropriate degree of presidential deference to the Court's rulings, ${ }^{127}$ as a

been respected by this Court and the Country as a permanent and indispensable feature of our constitutional system. It follows that the interpretation of the Fourteenth Amendment enunciated by this Court in the Brown case is the supreme law of the land ....

358 U.S. 1, 18 (1958) (quoting Marbury v. Madison, 5 U.S. (1 Cranch) 137, 177 (1803) (citation omitted)); see also Dickerson v. United States, 120 S. Ct. 2326, 2333 (2000) ("Congress may not legislatively supersede our decisions interpreting and applying the Constitution."); United States v. Morrison, 120 S. Ct. 1740, 1753 n.7 (2000) ("No doubt the political branches have a role in interpreting and applying the Constitution, but ever since Marbury this Court has remained the ultimate expositor of the constitutional text."); Kimel v. Florida Bd. of Regents, 120 S. Ct. 631, 644 (2000) ("The ultimate interpretation and determination of the Fourteenth Amendment's substantive meaning remains the province of the Judicial Branch.”); Planned Parenthood of Southeastern Pennsylvania v. Casey, 505 U.S. 833, 868 (1992) (describing the Supreme Court as "invested with the authority to ... speak before all others for [the American people's] constitutional ideals").

124. See, e.g., Paulsen, supra note 23.

125. See Eisgruber, supra note 53, at 348, 354-60 ("[N]o institution deserves the blind deference of other branches, and no institution enjoys unqualified supremacy with respect to all controversies, but, nevertheless, each institution will sometimes owe a constitutional duty of deference to the decisions (including erroneous decisions) of another branch."); Strauss, supra note 99, at 116 ("The answer depends on the particular constitutional provision at stake, and it requires difficult judgments of institutional competence."); see also Lawson \& Moore, supra note 47, at 1293-1301 (discussing distinctions between various forms of deference, summarizing positions of other commentators, and concluding that "actors who have an obligation independently to determine the right answer to constitutional questions will sometimes have an obligation to defer to the decisions of others when those others are more likely than is the actor to have found the right answer").

126. 1996 Dellinger Memorandum, supra note 101, at 3.

127. In addition to the sources discussed elsewhere in this article, significant recent commentary on the role of the political branches in interpreting the Constitution includes MARK TUSHNET, TAKING THE CONSTITUTION AwAY FROM THE COURTS (1999); Larry Alexander \& Frederick Schauer, On Extrajudicial Constitutional Interpretation, 110 HARV. L. REV. 1359 (1997); Louis Fisher, Constitutional Interpretation by Members of Congress, 63 N.C. L. REV. 707 (1985); Owen M. Fiss, The Supreme Court 1978 Term Foreword: The Forms of Justice, 93 HARV. L. REV. 1 (1979); Abner J. Mikva, How Well Does Congress Support and Defend the Constitution, 61 N.C. L. REV. 587 (1983); Lawrence Sager, Justice in Plain Clothes: Reflections on the Thinness of Constitutional Law, 88 NW. U. L. REV. 410 (1993); Symposium, Elected Branch Influences in Constitutional Decisionmaking, 56 LAW \& CONTEMP. Probs. 1 (1993); Symposium, Panel IV: The Role of the Legislative and Executive Branches in 
general matter, I find great merit in the intermediate approaches of Professors Eisgruber and Strauss. Yet even if greater interpretive independence is appropriate in some contexts, for non-enforcement of a law to constitute the faithful execution of the laws, it must be premised on and promote the best interpretation of the Constitution, which is not always that of the President. That is, the President's decisions must reflect the relative competencies of the branches as well as the vehicles for inter-branch dialogue conducive to principled constitutional interpretation.

Reasoned and productive debate between the President and Congress regarding the constitutionality of a statute can prove difficult in the best of circumstances, and particularly so during times of divided government when the discharge of many constitutional responsibilities may be greatly affected by unrelated political considerations. ${ }^{128}$ Presidential non-enforcement of congressional statutes seems an especially challenging context for constructive inter-branch constitutional dialogue (worse, for example, than in the course of lawmaking or litigation). Congress could be expected to respond as it sometimes has on the relatively rare occasions when Presidents have declined to enforce a statute: with hearings, outrage, and even impeachment. ${ }^{129}$ Congress also likely would employ unrelated constitutional powers to pressure the President to enforce laws, including withholding funding for programs the President desires and refusing to confirm the President's nominees.

Professor Paulsen argues that an escalation in heated conflicts between the President and Congress precipitated by routine non-enforcement, including more frequent consideration of impeachment, would be a welcome change, because it is "more likely that the law will be interpreted faithfully when that interpretation is the product of the interaction of competing views, fighting for either supremacy or consensus." 130 While inter-branch constitutional dialogue generally is beneficial, principled constitutional interpretation, or constitutional dialogue in any meaningful sense, is unlikely to thrive in the heat of the kinds of inter-branch battles that routine non-enforcement would spark. A regime in which the President were constitutionally compelled to thwart Congress's core function over any and all differences in constitutional interpretation seems a recipe for unproductive, politicized conflict-including nominations stalled and rejected, valuable programs killed, costly oversight, and even impeachmentwith each side likely to solidify its position or capitulate for reasons unrelated to the merits of the constitutional issue. ${ }^{131}$

Interpreting the Constitution, 73 CORNELL L. REV. 371 (1988); Symposium, Perspectives on the Authoritativeness of Supreme Court Decisions, 61 TUL. L. REV. 979 (1987); Symposium, supra note 81.

128. The Framers, of course, anticipated the occurrence of divisive political differences in the operation of government. See, e.g., THE FEDERALIST No. 51 (James Madison).

129. See generally 2 TRIAL OF ANDREW JOHNSON, supra note 62; Hearings, supra note 89; Department of Justice Authorization and Oversight: Hearings Before the Comm. on the Judiciary, supra note 89; Representation of Congress and Congressional Interests in Court: Hearings Before the Subcomm. on Separation of Powers of the Senate Comm. on the Judiciary, supra note 89.

130. Paulsen, supra note 23, at 330.

131. Professor Paulsen acknowledges that non-enforcement likely will cause "gridlock," but 
More conducive to principled constitutional analysis-and more in keeping with our constitutional structure-is an approach to non-enforcement that first encourages meaningful dialogue between Congress and the President in the course of enacting and repealing laws, and, if that fails, that typically favors the possibility of judicial review of constitutionally objectionable statutes. ${ }^{132}$ In addition to promoting reasoned deliberation, the President's approach to nonenforcement must reflect the institutional capacities of each of the branches to interpret the Constitution. Typically, and in the aggregate, the courts-ideally, informed by the views of the political branches-are likely to reach better constitutional outcomes in assessing the constitutionality of statutes than is a system of routine presidential non-enforcement. ${ }^{133}$ As Professor Eisgruber has written, "insulated from electoral control, required to justify decisions by written opinion, and selected partly on the basis of technical proficiency, judges have the opportunity, the incentive, and the ability to interpret the Constitution carefully." 134

Two centuries of experience establish that the President, too, is capable of principled constitutional interpretation. ${ }^{135}$ Presidents and their legal advisers have a long tradition of interpreting the Constitution in the exercise of presidential authority, and much of that constitutional analysis is memorialized in written legal opinions of Attorneys General or the Office of Legal Counsel. ${ }^{136}$

responds, "To a certain extent ... the framers intended gridlock as a consequence of separation of powers. What some today call 'gridlock,' they would have termed 'stability' and a guard against tyranny." Id. at 329; see also Strauss, supra note 99, at 125-26.

132. See Hearings, supra note 89, at 27-28 (testimony of Prof. Mark Tushnet) ("[R]efusing to comply with enacted legislation appears to thwart rather than promote a responsible dialogue.... Surely it is better... to structure the process of constitutional discussion in a less awkward and confrontational way. The veto provision seems admirably suited to the task.").

133. This is, of course, a matter of great dispute among legal commentators. See, e.g., Easterbrook, supra note 45, at 916-17, 925; Michael Stokes Paulsen, Protestantism and Comparative Competence: $A$ Reply to Professors Levinson and Eisgruber, 83 GEO. L.J. 385, 389-92 (1994).

134. Eisgruber, supra note 53, at 354-55. President James Madison, after leaving office, described certain institutional advantages possessed by the judiciary, and in so doing, qualified views he expressed in The Federalist Papers about the roles of the coordinate departments in interpreting the Constitution:

It is the Judicial department in which questions of constitutionality, as well as of legality, generally find their ultimate discussion and operative decision; and the public deference to and confidence in the judgment of the body are peculiarly inspired by the qualities implied in its members; by the gravity and deliberation of their proceedings; and by the advantage their plurality gives them over the unity of the Executive department, and their fewness over the multitudinous composition of the Legislative department.

Without losing sight, therefore, of the co-ordinate relations of the three departments to each other, it may always be expected that the judicial branch, when happily filled, will, for the reasons suggested, most engage the respect and reliance of the public as the surest expositor of the Constitution, as well in questions within its cognizance concerning the boundaries between the several departments of the Government as in those between the Union and its members.

4 LETTERS AND OTHER WRITINGS OF JAMES MADISON 349-50 (J.B. Lippincott 1867) (memorandum written in 1834).

135. See, e.g., Powell, supra note 19, at 530-40 (discussing what Powell terms "the executive branch perspective on constitutional law"). See generally H. JEFFERSON POWELL, THE CONSTITUTION AND THE ATTORNEYS GENERAL (1999).

136. The Attorney General has delegated to the Office of Legal Counsel the responsibility of 
Critics of presidential non-enforcement thus are mistaken to equate presidential refusals to enforce constitutionally objectionable laws with a line-item veto or dispensing authority, on the reasoning that Presidents routinely will convert policy objections into constitutional arguments. ${ }^{137}$

Nonetheless, proponents of routine non-enforcement too quickly dismiss concerns about the institutional limitations of presidential interpretation of the Constitution. Bad Presidents, they argue, can be impeached. But the problem is not simply a rare abusive President worthy of impeachment, but rather the expected tendencies of Presidents and their legal advisers engaged in good-faith constitutional interpretation. A tendency to augment presidential power and allow policy and political considerations to influence constitutional interpretation-or, at a minimum, whether to raise genuine constitutional objections in support of policy goals-inheres in the institution of the presidency. This tendency is not illegitimate, let alone grounds for impeachment. Indeed, the political perspectives reflected in presidential constitutional interpretation can contribute to its value. This tendency does, however, caution against defining presidential non-enforcement authority solely in terms of the President's own constitutional views.

Instead, presidential non-enforcement decisions should reflect deference to Supreme Court precedent and consideration of what course of action would encourage the possibility of judicial review. Professor Powell has observed that the executive branch's general practice of deferring to settled judicial doctrine provides "a significant check on the tendency of healthy institutional selfinterest to become simple institutional aggrandizement." ${ }^{138}$ Whatever deference is appropriate in the exercise of other presidential powers (for example, the veto and pardon powers), the President's obligation faithfully to execute the laws typically requires that he give the Court great deference when deciding whether to decline to enforce a law.

The possibility of judicial review of the President's constitutional views also often creates a salutary check on presidential interpretation, as well as an opportunity for productive constitutional dialogue. Thus, application of this second principle, like the first principle of respect for the constitutional lawmaking process, counsels the President in making non-enforcement decisions to consider, as one factor, the likely effect on the justiciability of the provision.

To recognize that, on the whole, courts are better suited to the business of constitutional interpretation does not require ignoring the significant limitations of judicial review. Judicial doctrines of deference and justiciability often diminish the effectiveness of the courts in blocking unconstitutional laws,

preparing formal legal opinions. Professor McGinnis describes opinions of the Attorneys General and the Office of Legal Counsel as comprising "the largest body of official interpretation of the Constitution and statutes outside the volumes of the federal court reporters." McGinnis, supra note 121 , at 376.

137. See May, supra note 21 , at 868,985 .

138. Powell, supra note 19, at 533. 
reflecting, in part, the institutional limitations of the judiciary, as well as a respect for the constitutional roles of the political branches. The courts typically sacrifice some measure of their own best view of whether a statute is constitutional and apply a general presumption of constitutionality and the extremely deferential rational basis standard of review. As discussed, though, Congress often does not actually consider the constitutionality of pending provisions-and the constitutional debate that does occur sometimes is perfunctory and in furtherance of policy and political concerns. As Paul Brest wrote, "few questions of constitutional interpretation lie entirely beyond the judiciary's reach. But many aspects of perfectly ordinary legislation are unreviewable, or at least are not actually reviewed, in practice."139

Non-enforcement policy should reflect that the perspectives brought by the political branches specially contribute to the determination of constitutional meaning, when, for example, the President or Congress possesses relevant expertise and where judicial review leaves constitutional norms, in the words of Professor Lawrence Sager, "underenforced." 140 Underenforced norms, according to Professor Sager's definition, result when the Court fails to enforce a constitutional provision to its full conceptual boundaries because of "institutional" concerns, such as questions of propriety or capacity. ${ }^{141}$ Professor Sager distinguishes this notion of institutional concerns from analytical reasons for limiting a judicial construct of a constitutional concept, which are based on an understanding of the concept itself. ${ }^{142} \mathrm{He}$ argues persuasively that where, because of institutional concerns, the courts do not fully enforce the Constitution, other governmental officials should be viewed as obligated, within the scope of their duties, to recognize underenforced constitutional norms as "in full force." 143

Relatedly, on some issues, the President and Congress possess superior interpretive ability as the result of special institutional expertise. As Professor Eisgruber has written, "there may be times when Congress or the Executive, by virtue of their connection to the people or their knowledge of what government can do, have the best insight into how the Constitution balances competing principles." ${ }^{144}$ The courts at times recognize the special competencies of the

139. Paul Brest, Congress as Constitutional Decisionmaker and Its Power to Counter Judicial Doctrine, 21 GA. L. REV. 57, 64 (1986). Brest offered as examples the reluctance of courts to invalidate laws on the grounds that they were enacted for unconstitutional purposes because of the difficulty of inquiring into legislators' motives, and the judicial practice of presuming that a law is supported by necessary facts without requiring that the legislature actually have engaged in fact-finding. See id. at 64-65; see also Lawrence Gene Sager, Fair Measure: The Legal Status of Underenforced Constitutional Norms, 91 HARV. L. REV. 1212 (1978).

140. SAGER, supra note 139, at 1212-13.

141. Id. at $1217-18$.

142. Id. at 1218 .

143. Id. at 1221.

144. Eisgruber, supra note 53, at 355. See generally Daniel O. Conkle, The Religious Freedom Restoration Act: The Constitutional Significance of an Unconstitutional Statute, 56 MoNT. L. REV. 39 (1995) (arguing that, although the Religious Freedom Restoration Act was unconstitutional, by enacting it Congress expressed contemporary values that should be relevant to how the Supreme Court 
political branches by deferring to their constitutional determinations in their areas of expertise and even declining to decide certain issues, for example, under the political question doctrine. That the President on some issues may have an interpretive advantage, however, does not support routine nonenforcement, but instead suggests a relevant factor for determining when the President may refuse to enforce a law. Not only should the President consider his own institutional expertise, but also whether Congress possesses relevant expertise and whether Congress has considered the constitutional issue, with the President freest to act on his own views when they do not negate Congress's considered views or foreclose further debate through the legislative or judicial processes.

IV

\section{Toward A Constitutional Policy of PREsidential Non- ENFORCEMENT}

The two principles I have suggested should govern presidential nonenforcement decisions will often, but not always, suggest the same response to a constitutionally objectionable law. Non-enforcement policy should not focus on one principle to the exclusion of the other. Rather, in cases of conflict, the President must undertake the occasionally difficult task of balancing competing constitutional concerns.

An exclusive focus, for example, on the second principle - the promotion of the Constitution and the determination of constitutional meaning-might suggest an intermediate approach that would call for the President to disregard laws that he views as unconstitutional whenever the President possesses special interpretive competence of relevance, relative to Congress and the Court. ${ }^{145}$ This form of limited non-enforcement would be far more in keeping with the constitutional structure and the President's constitutional responsibilities than routine presidential non-enforcement, but still would go too far in the direction of non-enforcement. Considered even in light of just the second principle, presidential interpretive autonomy on issues of special competence, without regard to other factors, might not adequately value the salutary effects the possibility of judicial review may have on the quality of constitutional interpretation, including the possibility of continued constitutional dialogue among the branches. More important, such an approach would not adequately

interprets the Free Exercise Clause).

145. David Barron develops a sophisticated version of this approach, worthy of close consideration, in the course of his thoughtful and thorough critique of approaches to presidential non-enforcement that he views as unduly court-centered. See Barron, supra note 87. I agree with much of Professor Barron's analysis, which forcefully conveys the importance to presidential non-enforcement decisions of an analysis of the relative interpretive abilities of all three branches. In the end, though, I continue to believe that the President's relative interpretive competence should constitute an important, but not exclusive, factor in presidential non-enforcement decisions. As discussed at greater length in the text, the principal problem with Professor Barron's focus on this one factor is its failure adequately to respect, not judicial power, but the constitutionally prescribed lawmaking process, including Congress's authority to act on its own constitutional views in the course of enacting enforceable laws. 
reflect the first principle I identified: respect for the integrity of the constitutionally prescribed lawmaking process. The Constitution, of course, addresses not only outcome, but also process. Implicit in our constitutional structure and the requirements of the Take Care Clause is a preference for ensuring the constitutionality of the laws through the process of lawmaking, rather than through the President's unilateral imposition of his constitutional views after enactment. In other words, the Constitution is better served when the President acts on his constitutional views to prevent the enactment of an unconstitutional law than when the President refuses to enforce an unconstitutional law.

When considered in combination, the two principles suggest a nonenforcement policy under which the President would decline to enforce a law only when he is specially situated to provide a needed check on an unconstitutional law and he can do so without threatening the constitutionally prescribed lawmaking process. The President's appropriate course often will be clear, but in some cases it will be uncertain. Translating the principles I have discussed into more specific factors to comprise presidential non-enforcement policy can help guide the President's response to particular constitutionally objectionable statutes.

\section{A. Factors That Have Guided Non-Enforcement Decisions}

Executive branch practice and policy suggest three principal factors to guide non-enforcement decisions. First, how clear is the provision's constitutional infirmity? Second, what effect would non-enforcement have on the prospects for judicial review of the statutory provision? Finally, does the provision encroach on executive power? In assessing these factors, I will focus on the 1994 Dellinger Memorandum, the executive branch's most recent, as well as most thorough, discussion of presidential non-enforcement. I will suggest some amendments to executive branch policy and, in the end, recommend six questions to guide non-enforcement decisions.

1. Clarity of the Constitutional Defect. The Dellinger Memorandum recognizes that an important factor in the President's decision whether to disregard a constitutionally objectionable statute is how clear the constitutional defect is. The Dellinger Memorandum also addresses the related central issue of the appropriateness of presidential deference to the constitutional views of the other branches. The Dellinger formulation requires the President to base his enforcement decisions not only on his own views but also on great deference to Congress and a prediction of how the Supreme Court likely would rule. If the Court likely would sustain the provision, the President "as a general matter" should enforce the provision. ${ }^{146}$ "If, however, the President, exercising his independent judgment, determines both that a provision would violate the Constitution and that it is probable that the Court would agree with him, the

146. 1994 Dellinger Memorandum, supra note 20, at 200. 
President has the authority to decline to execute the statute." ${ }^{147}$ Dellinger endorses a standard more permissive of non-enforcement for provisions that encroach on presidential powers.

Dellinger implicitly rejected the far more sweeping analysis offered by the Department of Justice during the previous Administration, which seemingly supported the President's authority routinely to decline to enforce constitutionally objectionable laws. ${ }^{148}$ Dellinger's formulation better reflects the appropriate respect for the constitutional functions and abilities of the other branches of government. ${ }^{149}$ I would suggest, though, several changes.

First, the Dellinger formulation appropriately recognizes that the President's constitutional views may differ from how the Supreme Court likely would rule (or has ruled) on the constitutionality of the provision, ${ }^{150}$ and both are relevant to non-enforcement decisions. The Dellinger test, however, is too tied to a prediction of the Court's views and does not sufficiently reflect other factors. Dellinger defines the scope of presidential authority relatively broadly, and then identifies additional factors that the President should consider, seemingly suggesting these other factors are discretionary. A better approach would recognize a broader range of factors, beyond predicting how the Court would rule, as relevant to whether the President constitutionally may disregard a law.

I do not agree, for example, that the President constitutionally may decline to enforce a provision whenever the President believes that the provision is unconstitutional and that it is merely "probable" that the Supreme Court would agree. I believe that in many instances in which it is merely probable the Court would hold a provision unconstitutional and the provision is not clearly unconstitutional, the course most consistent with the Constitution would require the President to enforce the provision and leave to the courts the task of reviewing the law. On the other hand, in some cases the Dellinger test is too demanding. For example, when non-enforcement likely is the only way to allow for judicial resolution of the issue, non-enforcement may be appropriate even if the President cannot say that it is probable that the Court would agree with his interpretation. Indeed, it often will be difficult for the President to predict with confidence how the Court would rule.

Second, I would add to the Dellinger formulation that the President's own constitutional views should play a greater role when the presidency, as an institution, possesses special expertise such that the President's views on at least some aspect of the constitutional issue are likely to be superior to those of the Court and to any considered view Congress seems to have been expressing.

147. Id.

148. See supra text accompanying notes 38-43.

149. Dellinger, however, cites the earlier memoranda for support without acknowledging the substantial differences in views. Dellinger's formulation is closer to that of Attorney General Civiletti. See supra Part III.A.

150. See 1994 Dellinger Memorandum, supra note 20, at 200-01. 
The President's views may be deserving of added weight, for example, on issues regarding which the courts typically defer to the political branches or treat as nonjusticiable and entrust to the executive branch, either alone or together with Congress.

Finally, the Dellinger Memorandum directs that " $[\mathrm{t}]$ he President should give great deference to the fact that Congress passed the statute and that Congress believed it was upholding its obligation to enact constitutional legislation." This mirrors the deference courts give to congressional enactments absent circumstances that trigger closer scrutiny. Deference to Congress also is fitting on the part of the President, but in light of the congressional practice of bundling together unrelated provisions in a single bill and often not actually considering the constitutionality of every provision, the President should consider whether the facts support or rebut the presumption of constitutionality and enforceability. I would add to the Dellinger formulation that the President should consider available evidence concerning whether Congress, in fact, expressed a constitutional judgment in enacting the statute. Presidential enforcement policy should reflect that members of Congress do not feel, and should not be viewed as, constitutionally bound to vote against any bill containing any unconstitutional provision-just as the executive branch's view long has been that the President need not veto all such bills. ${ }^{152}$ Presidential nonenforcement, for example, is far more likely the appropriate response to a constitutionally objectionable rider to an appropriations bill added by a single member of Congress with no evidence that other members considered the issue, than to a provision about which Congress held hearings and issued a report addressing the constitutional issue. Presidential consideration of this factor would both promote reasoned deliberation about constitutional meaning and respect Congress's authority to pass laws that reflect constitutional views that differ from the President's.

The least constitutionally troubling circumstance for non-enforcement is presented when a provision is clearly unconstitutional as a matter of both executive and judicial interpretation and no evidence exists (beyond passage of the law) that Congress actually intended to express a constitutional view to the contrary. When the President believes the constitutional defect clear, and has virtually no doubt as to how the Supreme Court would rule, not enforcing the statute typically presents no threat to the authority of the other branches. The President expedites the implementation of judicial determinations by not enforcing statutes that are unconstitutional under the Court's rulings. The alternative would require separate litigation of every application of a constitutional rule, imposing on private individuals pointless expense and hardship.

Non-enforcement of a clearly unconstitutional provision often will arise when a decision of the Supreme Court regarding one law renders other

151. Id. at 200 .

152. See, e.g., Signing Statements Memorandum, supra note 14, at 134-35. 
previously enacted statutes unconstitutional, so Congress could not have considered the constitutional issue in light of the Court's views. Judge Easterbrook offers as one example that following the Supreme Court's invalidation in the 1970s of several statutes that discriminated on the basis of sex, the executive branch reviewed analogous laws and stopped complying with those that violated the guarantee of equal protection as interpreted by the Court. ${ }^{153}$ In Judge Easterbrook's words, presidential non-enforcement in such circumstances "speeds up the process of compliance with constitutional norms." 154 Non-enforcement is also typically the correct response when the courts have not addressed a question, but its proper resolution is so clear that there can be no genuine dispute, and enforcing the provision would subject people to unjustifiable harm and expense.

Yet, in deciding whether to refuse to enforce even a law that is clearly unconstitutional in light of both the President's view and controlling Supreme Court precedent, the President also should consider any available indications of Congress's actual views. Congress on rare occasion knowingly enacts statutes that are flatly inconsistent with Supreme Court precedent, precisely because Congress disagrees with that precedent. Enforcement may be appropriate where Congress's considered judgment might cause the Supreme Court to reconsider or modify its conclusion, because, for example, Congress possesses special competence relevant to the constitutional issue and engaged in relevant fact-finding.

2. Effect on Justiciability. A second factor seems to have played a greater role in practice than in the executive branch's written expressions of nonenforcement policy: the effect non-enforcement would have on the likelihood of judicial review of the provision. The Dellinger Memorandum states, without further elaboration, that

[a]lso relevant is the likelihood that compliance or non-compliance will permit judicial resolution of the issue. That is, the President may base his decision to comply (or decline to comply), in part on a desire to afford the Supreme Court an opportunity to review the constitutional judgment of the legislative branch. ${ }^{155}$

This assertion seems correct, but somewhat understated. Whenever the President contemplates non-enforcement, he should consider the likely effect on the possibility of judicial review.

The effect on judicial review is relevant not because of a potential deprivation of judicial power in violation of Article III. The Ninth Circuit was wrong to conclude that presidential non-enforcement unconstitutionally usurps the constitutional function of the judiciary. ${ }^{156}$ Rather, as discussed at length

153. See Easterbrook, supra note 45, at 913.

154. Id. at $928-29$.

155. 1994 Dellinger Memorandum, supra note 20, at 201.

156. See supra text accompanying notes 30-32 (discussing Lear Siegler, Inc. v. Lehman, 842 F.2d 1102, 1125 (9th Cir. 1988), withdrawn in part on other grounds, 893 F.2d 205 (9th Cir. 1989) (as amended, Jan. 10, 1990) (en banc) (per curiam)). 
above, judicial review of statutes generally fosters better constitutional outcomes and is more consistent with the constitutional allocation of lawmaking powers. This factor merits greatest weight at the extremes, when either refusing to enforce a law or complying with a law would render the constitutional issue nonjusticiable. While the President always should assess the effect nonenforcement would have on judicial review, relevant too is how effectively the courts are likely to enforce the constitutional norm at issue. For example, judicial review will prove far more effective on issues for which the Court employs heightened scrutiny than where the Court will uphold the statute upon a mere finding of rationality. This factor merits less weight to the extent the issue involved is one on which the courts defer to the institutional expertise of the President or Congress. ${ }^{157}$

The conflict that led to the Supreme Court opinion in United States v. Lovett $^{158}$ helps illustrate the relevance of justiciability to the legitimacy of presidential non-enforcement. During World War II, President Roosevelt signed into law a defense appropriations bill that prohibited paying the salaries of three named federal employees Congress viewed as subversives. ${ }^{159}$ President Roosevelt declared that the provision was unconstitutional, but that the exigencies of war required him to sign the bill. ${ }^{160}$ Had the President simply ignored this prohibition, he likely would have rendered the issue nonjusticiable. Instead, he permitted the employees to work, but did not pay them, providing them a legal claim for their salaries. ${ }^{161}$

In other cases, the President would substantially increase the likelihood of judicial review by not complying with a statutory provision, as in the case of President Andrew Johnson's alleged violation of the Tenure of Office Act. Particularly when non-enforcement creates the only possibility of judicial review, the President makes possible a constitutional check on unconstitutional laws that the courts otherwise would not provide. The President's refusal to enforce the provision at least potentially would be a temporary measurethough of possibly long duration-until the courts were presented with an opportunity to resolve the matter. By declining to enforce the provision, the President would not impose his own views to the exclusion of the other branches, but would create the possibility of further dialogue among the branches in the context of litigation.

Judge Easterbrook warned against the efficacy of judicial review by noting that it took the Court sixty years to decide the constitutional issue raised by the Tenure of Office Act and 163 years to declare that the Sedition Act of 1798 had been unconstitutional. ${ }^{162}$ In some cases, though, litigation is certain to ensue if

157. See supra notes $139-45$ and accompanying text.

158. 328 U.S. 303 (1946).

159. See id. at 305 n.1.

160. See id. at 313.

161. See id. at 305.

162. See Easterbrook, supra note 45, at 928. 
the President enforces a provision, as was the case in Lovett, which involved federal employees working without pay, and also was true of the provision that directed President Clinton to discharge HIV-positive service members.

In many cases, however, whether or not the President enforces a law will not affect the likelihood of judicial review. When judicial review is a possibility regardless of the President's action, the enforcement decision should depend on other factors, with enforcement typically the constitutionally dictated course. In addition to the factor already discussed-the clarity of the constitutional defect, which should be considered in light of the constitutional views of all three branches and their relative interpretive capacities-the President also should weigh the nature and magnitude of the harm that would result from enforcement. ${ }^{163}$

A relatively small number of statutes will be nonjusticiable whether or not the President enforces them. A relatively high percentage of such statutes are likely to involve the constitutional allocation of powers among the branches. When barriers to judicial review prevent the courts from providing a check on constitutionally objectionable statutes, and litigation is unavailable as a forum for further dialogue, the President should play an enhanced role in protecting the constitutional structure and the public from the effects of unconstitutional laws. Congress, then, will be left with limited, though still significant ability to check presidential abuses, including oversight, funding, and the ultimate power of impeachment and removal.

Consideration of the likelihood of judicial review raises the question of what position the President should take in litigation challenging the constitutionality of a law he views as unconstitutional. The executive branch historically has described the standards governing the enforcement and defense of statutes in similar-often identical-terms. ${ }^{164}$ The Department of Justice routinely defends statutes that are unconstitutional under the President's view, as well as under the best understanding of applicable judicial precedent, as long as a reasonable argument can be made in their defense. ${ }^{165}$ As in the non-enforcement context, the Department recognizes an exception to this rule for statutes that encroach on executive power. ${ }^{166}$ Strong arguments exist for generally following a policy of defending statutes of questionable constitutionality. ${ }^{167}$

On the other hand, executive branch policy in this area should acknowledge that the constitutional concerns raised by non-enforcement and non-defense are

163. See 1994 Dellinger Memorandum, supra note 20, at 201.

164. See 1980 Civiletti Memorandum, supra note 20; see also Chrysanthe Gussis, Note, The Constitution, the White House, and the Military HIV Ban: A New Threshold for Presidential NonDefense of Statutes, 30 U. MICH. J.L. REFORM 591, 591 (1997) (describing and endorsing an "emerging practice that allows the President to meet a lower threshold of unconstitutionality before declining to defend legislation").

165. See Drew S. Days, III, The Solicitor General and the American Legal Ideal, 49 SMU L. REV. 73, 79-80 (1995).

166. See id.

167. See id. 
not identical. Non-enforcement typically is by far the more constitutionally problematic course in that it more directly challenges Congress's core legislative function and threatens the integrity of the lawmaking process. By contrast, if Congress is denied representation by the Department of Justice, Congress remains free, through other attorneys, to present its defense of the statute in the litigation. In some circumstances the President best can promote reasoned constitutional dialogue among the branches, and, in turn, the search for constitutional meaning, by offering a court his actual constitutional views, rather than the best defense he can craft of a statute that he believes is unconstitutional. Particularly when the President possesses special expertise of relevance, a stake in the outcome (for example, a dispute over presidential powers), or a perspective that differs from that of Congress, the President more often should consider, as an alternative to non-enforcement, refusing to defend, or even arguing against, a constitutionally objectionable law in litigation and leaving the law's defense to Congress. The President would thereby allow the courts to resolve the constitutionality of the statute, rather than impose his own views, and both the President and Congress could seek to inform that decision through their participation in the litigation.

Again, the position taken by President Roosevelt in Lovett is instructive. President Roosevelt's Department of Justice refused to defend the statute requiring the discharge of the employees in the litigation that ensued, and instead argued to the Court that the law was unconstitutional. Congress retained its own lawyers to defend the law and provide the Court with its constitutional perspective. The Court ultimately agreed with the President and declared the law unconstitutional-a result more in keeping with our constitutional structure than if the President had resolved the issue unilaterally by refusing to comply with the provision.

3. Statutes that Encroach on Executive Authority. The Dellinger Memorandum describes the President's non-enforcement authority as greatly enhanced when the law encroaches on the constitutional powers of the presidency: "Where the President believes that an enactment unconstitutionally limits his powers, he has the authority to defend his office and decline to abide by it, unless he is convinced that the Court would disagree with his assessment." 168 The Dellinger position is consistent with past executive branch policy and practice. ${ }^{169}$

The executive branch typically has justified enhanced non-enforcement authority when the President's powers are threatened as necessary to selfdefense, and, in turn, preservation of the constitutional balance of powers. The 1980 Civiletti Memorandum describes this rationale well: "[T]he Executive can rarely defy an Act of Congress without upsetting the equilibrium established within our constitutional system; but if that equilibrium has already been placed

168. 1994 Dellinger Memorandum, supra note 20, at 201.

169. See 1980 Civiletti Memorandum, supra note 20, at 56. 
in jeopardy by the Act of Congress itself, the case is much more likely to fall within that narrow class." ${ }^{" 170}$

Some commentators have countered that it is precisely when Presidents are protecting their own powers that we should be most suspicious of their constitutional analysis, and that Presidents perhaps should be less free to disregard laws they believe threaten presidential power than laws they believe violate individual rights. ${ }^{171}$ Allowing the President to resolve disputes with Congress over their respective constitutional powers by refusing to enforce laws does create the opportunity for self-interest inappropriately to taint constitutional analysis. The alternative, though, of requiring Presidents invariably to comply with laws that aggrandize Congress's power at the expense of presidential power would pose too great a threat to our constitutional equilibrium. Given the nature of legislative encroachments on executive power, if Presidents consistently were to comply with such laws, the courts would not provide a sufficient check to protect the constitutional balance of powers. Steady compliance likely would produce a steady erosion of presidential power.

While this final non-enforcement factor endorsed by the executive branch is the most controversial, the fact that a provision encroaches on presidential power rarely, if ever, should be determinative. On closer scrutiny, what appear to be reasons for giving the President greater authority to refuse to enforce laws that threaten presidential powers may be better viewed as applications of other relevant and less controversial considerations-namely, justiciability, presidential expertise, the magnitude of the constitutional harm, and the degree of congressional attention to the constitutional issue.

A principal reason courts may inadequately protect against congressional encroachments on presidential authority is that presidential compliance with such statutes is particularly likely to deprive the courts of any opportunity for review. Presidential compliance with the Tenure of Office Act and its successors, for example, would have allowed the Senate unconstitutional control over the President's ability to remove officers, with no possibility of judicial review. By contrast, where presidential non-enforcement would render the issue nonjusticiable, compliance may be the constitutionally preferred course, even when the subject matter is one of presidential power. For example, it was only by complying with the legislative veto at issue in Chadha ${ }^{172}$ that the President created the opportunity for the Supreme Court to consider its constitutionality.

In addition, many types of legislative encroachments are unlikely ever to present a justiciable case or controversy that would allow for judicial review, or will be subject only to an extremely deferential review. A greater need for a

170. Id; see also Steven G. Calabresi \& Christopher S. Yoo, The Unitary Executive During the First Half-Century, 47 CASE W. RES. L. REV. 1451, 1463-72 (1997).

171. See Hearings, supra note 89, at 44-45 (testimony of Prof. Sanford Levinson); id. at 54-55 (Prof. Mark Tushnet's responses to questions).

172. See Immigration \& Naturalization Serv. v. Chadha, 462 U.S. 919 (1983). 
presidential check exists, for example, when Congress seeks to encroach on the President's authority as commander in chief or other foreign affairs powers. The Dellinger Memorandum recognizes that provisions that diminish presidential power often are not justiciable or only will be justiciable if the President declines to enforce them. ${ }^{173}$ The President also typically has special expertise relevant to assessing the constitutionality of legislative encroachments on presidential power. Non-enforcement therefore more often will be the constitutionally preferred course for laws that interfere with the President's foreign affairs powers, than, for example, for laws that the President believes violate individual rights, other factors being equal.

Finally, in considering the harm imposed by a law that diminishes presidential power, Presidents should consider not their interests narrowly defined, but the long-term effects on the institution of the presidency. Overly zealous non-enforcement is not the only danger. In some instances, Presidents may be reluctant to provoke a confrontation with Congress to prevent what, viewed narrowly, seems a relatively minor encroachment. Presidents confronted with laws they believe unconstitutionally impair presidential power should consider their obligation to preserve the constitutional powers of the presidency and pass the office on to their successors unimpaired.

\section{B. Recommendations for Process and Questions to Guide Non-Enforcement Decisions}

As explored above, essential to the argument that the President's duty to faithfully execute the laws in some circumstances permits presidential nonenforcement of laws on constitutional grounds is the President's competence as an interpreter of the Constitution. For this reason, the President possesses enhanced authority to act on his own views of the Constitution when he possesses institutional expertise of relevance to the constitutional issue at hand. Also critical to the quality of the President's constitutional views is how he comes to those views. Paul Brest has argued that Congress's authority to interpret the Constitution in a manner that differs from the courts depends in part on whether "Congress develops trustworthy procedures for determining constitutional issues." similarly depends in part on whether he relies upon standards and procedures that promote responsible decisionmaking. As Professor Sanford Levinson aptly has observed, "[a] central question . . . concerns the process by which a President (or Attorney General) should be expected to come to conclusions about constitutional meaning." $" 175$

173. See 1994 Dellinger Memorandum, supra note 20, at 201.

174. Brest, supra note 139 , at 59.

175. Levinson, supra note 47, at 379; see also Rappaport, supra note 52, at 779-83 (arguing that, although not constitutionally required, a practice of regular issuance of presidential legal opinions justifying non-enforcement decisions would improve the exercise of non-enforcement power and protect against its abuse). 
Presidents should promulgate and adhere to substantive and procedural guidelines aimed at maximizing the quality of the constitutional interpretations that govern non-enforcement decisions. Existing substantive guidelines, particularly the 1994 Dellinger and 1980 Civiletti Memoranda, provide a valuable beginning. Presidents should continue to develop a comprehensive and coherent non-enforcement policy that articulates the governing substantive factors and their conceptual justifications. The Constitution does not mandate one particular formulation, but I recommend that the following questions guide non-enforcement decisions:

(1) How clear is the law's constitutional defect?

(2) Does the President possess institutional expertise relevant to resolving the constitutional issue, and what are the relative interpretive abilities of the three branches?

(3) Did Congress actually consider the constitutional issue in enacting the law?

(4) What is the likelihood of judicial review and how would non-enforcement affect that likelihood?

(5) How serious is the harm that would result from enforcement?

(6) Is repeal of the statute or non-defense of the statute against legal challenge an effective alternative to nonenforcement?

As a preliminary matter, the President also should explore any available alternatives that would avoid the constitutional problem, including urging Congress to correct the problem before passage, adopting a saving construction of the provision, and considering the possibility of a veto.

In addition, the President should issue mandatory procedures to govern how non-enforcement decisions are made. A good model can be found in a memorandum issued by President Reagan, and still followed by the executive branch, establishing procedures for the assertion of executive privilege. ${ }^{176}$ The President must make the ultimate decision to assert executive privilege, and his decision follows written recommendations from the Attorney General and the Counsel to the President. ${ }^{177}$ The ultimate decision not to enforce the clear dictates of a statute often is of sufficient importance that it also should be made by the President. ${ }^{178}$ When Congress's statutory directive is unambiguous and not susceptible to a saving construction or avoidance of unconstitutional applications through discretionary enforcement decisions, and controlling judicial precedent does not resolve the constitutional issue, the President

176. Memorandum from President Ronald Reagan to the Heads of Executive Departments and Agencies, Procedures Governing Responses to Congressional Requests for Information (Nov. 4, 1982), reprinted in H.R. Rep. No. 99-435, 99th Cong., 1st Sess 1106 (1985) (report on Department of Justice role in withholding of EPA documents from Congress).

177. See id.

178. See id. 
personally should make the call. As in the case of assertions of executive privilege, written recommendations from the Attorney General and the Counsel to the President would best guide the President's non-enforcement decisions. The procedures for non-enforcement should require congressional notification and the preparation by the Department of Justice of a written opinion analyzing the constitutional issue. ${ }^{179}$ The opinion should be made publicly available so that the extraordinary decision and rationale not to enforce a statute will be subject to public scrutiny. ${ }^{180}$

\section{$\mathrm{V}$}

\section{An APPLICATION: THE HIV PROVISION}

The principles and factors I have suggested should govern presidential nonenforcement decisions, while not as simply applied as an approach of mandatory enforcement or routine non-enforcement, almost always will yield a clear presidential response, and usually will require enforcement of the constitutionally objectionable provision. On relatively rare occasions, though, the relevant constitutional norms will conflict and require the President to make a difficult judgment as to how best to fulfill his obligation to ensure the faithful execution of the laws. This concluding section will consider a hard case: the example with which this article began, the HIV provision enacted as section 567 of the National Defense Authorization Act for Fiscal Year $1996{ }^{181}$

Section 567 unambiguously ordered the discharge of members of the armed forces who were HIV-positive "as soon as practicable" and not later than six months after a service member was diagnosed as HIV-positive. ${ }^{182}$ The discharge was mandatory and did not depend on the ability of affected individuals to perform their duties. ${ }^{183}$ The HIV provision could not be construed in a manner that would avoid what was in President Clinton's view an unconstitutional discharge of valuable service members. President Clinton announced that he

179. Professor Levinson has argued that only the Solicitor General should be entrusted with the task of writing legal opinions explaining the basis for non-enforcement. See Levinson, supra note 47, at 38081. Professor Paulsen has responded that the Office of Legal Counsel is the more appropriate office. See Paulsen, supra note 133, at 388. I would leave to the Attorney General the decision who writes and signs the opinion. A process that would require the President to make the non-enforcement decision, on the advice of the Attorney General and the Counsel to the President, would provide appropriate safeguards. I would note, however, that a principal function of the Office of Legal Counsel is to prepare the legal opinions of the Department of Justice.

180. Current law already requires the Attorney General to notify Congress if the Department of Justice determines that it will not enforce a provision of law because the Department believes the provision is not constitutional, or that it will not defend a provision of law against constitutional challenge. See supra note 90. The President also often notifies Congress and the public through language in a signing statement when he signs a law with the intention of refusing to enforce a provision on constitutional grounds. See supra note 14.

181. See Pub. L. No. 104-106, § 567, 110 Stat. 186 (1996), repealed by Act of Apr. 26, 1996, Pub. L. No. 104-134, tit. II, § 2707(a)(1), 110 Stat. 1321, 1321-30 (codified as amended at 10 U.S.C. $\S 1177$ (Supp. IV 1998)).

182. Id. See id.

183. The provision contained an exception for persons who were within two years of retirement. 
would seek repeal of the provision and would not defend it against constitutional challenge, but he would enforce it unless a court directed otherwise. $^{184}$

Was President Clinton's response constitutionally appropriate? At least on a superficial level, the answer clearly is yes. Under my proposed analysis, the final factor-whether effective alternatives to non-enforcement exist-would seem dispositive. The President was successful in working with Congress to repeal the provision just two months after it was enacted and four months before its effective date. ${ }^{185}$ When repeal is possible, it is a constitutionally required alternative to non-enforcement. The simplicity of this answer, though, is deceptive. As application of the factors reveals, the characteristics of the HIV provision rendered the decision whether to enforce it particularly difficult.

Most important, the decision whether to seek a repeal of a law cannot be made in isolation from an assessment of the other factors relevant to the legitimacy of non-enforcement. The likelihood of success of a repeal effort often is difficult to evaluate, and the prospects for success are greatly weakened by the specter of non-enforcement. Congress has little incentive to repeal a statute the President will not enforce in any event, and the President is far less likely to expend limited resources trying to repeal a statute he will refuse to enforce. The enforcement decision, therefore, must often be made, as was the case here, without the knowledge of whether a repeal effort will be successful.

A preliminary question relevant to the legitimacy of non-enforcement is whether President Clinton adequately sought to remedy his constitutional concerns during the lawmaking process, and, in particular, whether he was justified in signing, rather than vetoing, the bill. President Clinton had vetoed an earlier bill in part because it contained a provision comparable to section 567. When Congress passed a new version of the Defense Authorization Act and again included the HIV provision, President Clinton noted in his signing statement that he believed the provision was unconstitutional, but that he nonetheless felt he had to sign the Act:

[C]ongress has addressed my three central national security concerns about the earlier bill.... The Act also includes a number of provisions of great importance to our national defense and to the men and women in our armed forces, authorizing critical defense programs to be continued and new ones to be initiated. ${ }^{186}$

President Clinton thus did strongly press his objections prior to enactment. ${ }^{187}$

Proceeding now to the first of the six factors, how clear is the law's

184. Signing Statement, supra note 2, at 227.

185. See Act of Apr. 26, 1996, Pub. L. No. 104-134, tit. II, § 2707(a)(1), 110 Stat. 1321, 1330.

186. Signing Statement, supra note 2, at 226. Among the specific provisions of importance the President cited were a pay increase for military personnel, an initiative to improve military housing and facilities, improvements in procurement policies, and a provision to allow the extradition of indicted war criminals and the provision of evidence directly to the International War Crimes Tribunals for the Former Yugoslavia and Rwanda. See id.

187. Whether the need for the other provisions of the Act was sufficiently compelling to justify forgoing a second veto is a difficult judgment, not easily second-guessed, that the Constitution requires of the President. 
constitutional defect? The HIV provision cannot be described as clearly unconstitutional under prevailing judicial precedent, but for reasons that render application of this factor complicated. The President stated his constitutional judgment that section 567 denied service members the equal protection of the laws by denying them their jobs without furthering a legitimate governmental purpose. ${ }^{188}$ He further stated that the provision was "blatantly discriminatory and highly punitive." ${ }^{\prime 19}$ The President based this conclusion on advice provided by the Department of Justice concerning the appropriate legal standard. A court reviewing this provision would have applied the same rational basis standard but likely would have upheld the provision. As Professor H. Jefferson Powell has written, a court almost certainly would have considered section 567 through "screens of deference" out of respect for the political process and Congress's legislative role and would have "underenforced the underlying equal protection norm." 190

Second, and relatedly, does the President possess institutional expertise relevant to resolving the constitutional issue, and what are the relative interpretive abilities of the three branches? This factor clearly weighed in favor of non-enforcement. While the courts very likely would have upheld the HIV provision under a highly deferential standard of review, the President brought considerable expertise to the issue in his role as commander in chief. The President appropriately considered the likely effect of section 567 and concluded that discharging healthy, trained, and productive members of the military would be detrimental to military efficiency and effectiveness. President Clinton based his assessment on advice provided by the Department of Defense and the Chairman of the Joint Chiefs of Staff concerning the effect on the military of the discharge. The President's signing statement explained that

the Secretary of Defense and the Chairman of the Joint Chiefs of Staff have advised me that the arbitrary discharge of these men and women would be both unwarranted and unwise; that such discharge is unnecessary as a matter of sound military policy; and that discharging service members deemed fit for duty would waste the [g]overnment's investment in the training of these people and would be disruptive to

188. "I have concluded that this discriminatory provision is unconstitutional. Specifically, it violates equal protection by requiring the discharge of qualified service members living with HIV who are medically able to serve, without furthering any legitimate governmental purpose." Id. at 227.

189. Id. at 226 .

190. H. Jefferson Powell, The Province and Duty of the Political Departments, 65 U. CHI. L. REV. 365, 382-83 (1998) (book review). Professor Powell assessed the HIV provision against the Court's recent articulation of its rational basis test:

In areas of social and economic policy, a statutory classification that neither proceeds along suspect lines nor infringes fundamental constitutional rights must be upheld against equal protection challenge if there is any reasonably conceivable state of facts that could provide a rational basis for the classification. Where there are "plausible reasons" for Congress' action, "our inquiry is at an end."

[I]t is entirely irrelevant whether the conceived reason for the challenged distinction actually motivated the legislature.

FCC v. Beach Communications, 508 U.S. 307, 313-15 (1993) (citations omitted). 
the military programs in which they play an integral role. ${ }^{191}$

Congress, too, possessed expertise relevant to the issue but, as discussed in more detail under the next factor, did not engage in an assessment of the constitutional issue.

Third, did Congress actually consider the constitutional issue in enacting the law? The answer to this question is complicated by the procedural history of the HIV provision. It is significant that Congress enacted the provision a second time, after a presidential veto. In his veto message, President Clinton cited several "serious constitutional concerns" unrelated to the HIV provision, and then added "H.R. 1530 also contains two provisions that would unfairly affect certain service members. One requires medically unwarranted discharge procedures for HIV-positive service members." not state his objections in constitutional terms at the time of his veto, so he did not give Congress a full opportunity to assess and respond to his constitutional concerns. Moreover, the legislative history of the bill suggests that Congress did not consider the constitutionality of the provision and paid little attention at all to the provision. A House committee report stated "the retention of such personnel degrades unit readiness and fails to protect deployment equity among service members." ${ }^{193}$ Neither house, however, debated or held hearings on either the constitutionality of or the need for the provision, which was one of many in the Defense Authorization Act. ${ }^{194}$ The provision originally was attached as a rider to the bill in the House, after it passed the Senate, and its sponsor emphasized his (mistaken) belief that HIV invariably was contracted as the result of misconduct in violation of the Uniform Code of Military Justicethrough illegal drug use, heterosexual sex with prostitutes, or homosexual sexual activity. ${ }^{195}$ President Clinton, through a spokesperson, described the provision as "mean-spirited" and suggested that the actual purpose behind it was an illegitimate one. ${ }^{196}$

191. Signing Statement, supra note 2, at 227. At a press conference explaining the President's decision, Assistant Attorney General Walter Dellinger explained further:

We advised the President that this provision, which discriminates against a group of healthy and productive members of the Armed Services, would be constitutional only if it serves a legitimate governmental purpose. After consulting with Secretary Perry and the Joint Chiefs, the President concluded that the provision does not serve any valid military or other purpose. Based on the Pentagon's military conclusion, and after consulting with the Department of Justice about the legal effect of those conclusions, the President appropriately determined that the provision is unconstitutional and that the Department of Justice should not defend its constitutionality in any litigation.

White House Briefing by Counsel to the President Jack Quinn and Assistant Attorney General Walter Dellinger, Feb. 9, 1996, available in 1996 WL 54453 (White House) [hereinafter White House Briefing].

192. Veto Message, supra note 4.

193. H.R. REP. NO. 104-31, at 223 (1995).

194. See id. at 654,657 (noting that the HIV provision was adopted without any hearings or inquiry into the issue); see also 142 CONG. REC. H12-22 (daily ed. Jan. 3, 1996); Gussis, supra note 164, at 59496.

195. See 141 Cong. ReC. H31,406 (1995); 142 Cong. ReC. H1213-14 (daily ed. Feb. 1, 1996) (statement of Rep. Dornan).

196. White House Briefing, supra note 191. 
Fourth, what is the likelihood of judicial review and how would nonenforcement affect that likelihood? There was no question that discharged service members would challenge the constitutionality of the HIV provision if it were enforced. If, instead, the President had ordered the military not to comply with the law, these service members would have suffered no injury and would have had no incentive, or standing, to challenge the law. As discussed in more detail in connection with the final factor, though, the potential inefficacy of judicial review greatly complicates the non-enforcement decision.

Fifth, how serious is the harm that would result from enforcement? This factor weighed heavily in favor of non-enforcement. More than one thousand members of the military with a life-threatening condition faced the loss of jobs and benefits. The President, however, possessed some ability to mitigate what he viewed as serious harm to individuals in derogation of their constitutional rights, at least pending judicial resolution of the constitutionality of the provision. For example, he directed the Secretaries of Defense, Veterans Affairs, and Transportation in implementing the provision to take all necessary steps to ensure that service members and their families received all benefits to which they were entitled, including all available disability, health care, and vocational educational benefits. ${ }^{197}$ Moreover, had the repeal not foreclosed judicial review, the President could have supported the issuance of a preliminary injunction pending judicial resolution.

Finally, is repeal of the statute or non-defense of the statute against legal challenge an effective alternative to non-enforcement? As mentioned above, the fact that the constitutionally preferred course of repeal ultimately proved available here is important but not entirely dispositive, because the President could not have been certain that Congress would repeal the provision at the time he made his enforcement decision. Non-defense of the provision also was an option, and was the course the President announced he would take if his repeal effort was not successful, but its efficacy too was uncertain. The litigation that inevitably would have ensued would have allowed Congress to inform the court of its constitutional views in defense of the provision and the President to present his view that the discharge would violate the guarantee of equal protection. In his signing statement, the President noted that the House and Senate would have the opportunity to "if they wish, present to the courts their argument that the provision should be sustained."198 The courts, however, ordinarily would apply to the HIV provision the highly deferential rational basis standard of review. In this regard, the HIV provision presents a more difficult case than the law at issue in Lovett. The courts were more likely to, and ultimately did, effectively protect the constitutional rights of the plaintiffs in Lovett by invalidating the unconstitutional statute, after hearing the competing views of the President and Congress. ${ }^{199}$

197. See Signing Statement, supra note 2, at 227.

198. Id.

199. 328 U.S. 303 (1946). 


\section{VI}

\section{CONCLUSION}

The HIV provision presents an unusually difficult case and powerfully illuminates the complexity of a President's constitutional obligation when confronted with a constitutionally objectionable law. The cumulative import of the six questions I have suggested should guide non-enforcement decisions does not dictate a clear response. Nor do the two principles from which I derived the questions. Applying the first principle, the integrity of the constitutionally prescribed lawmaking process was best promoted by President Clinton's chosen course: attempted repeal, and if unsuccessful, a presentation of the President's and Congress's competing views to the courts. The second principle, howeverthe promotion of constitutional norms over unconstitutional statutes and the determination of constitutional meaning-weighed in favor of non-enforcement because the President possessed interpretive expertise to which the courts probably would not have given full force. Moreover, Congress, to which the courts likely would have deferred, enacted the provision as one of many, without express attention to its constitutionality.

Though a close question, the best course here seems the one chosen by President Clinton, with the caveat that, had the repeal effort failed and litigation ensued, a strong argument could have been made against affording Congress the extreme degree of judicial deference that usually accompanies rational basis review. That argument would proceed as follows. When the President takes the extraordinary step of offering a court his considered judgment that a statutory provision is unconstitutional, and he possesses relevant interpretive expertise, judicial review should be more searching and assess the constitutional views presented by both the President and Congress, in light of their relative interpretive expertise. The reviewing court also should consider the extent to which Congress actually considered the constitutional issue in enacting the provision, rather than apply the usual rule under rational basis review that finds "entirely irrelevant for constitutional purposes whether the conceived reason for the challenged distinction actually motivated the legislature." ${ }^{200}$ The difficulties inherent in the courts playing an enhanced role of this kind in scrutinizing acts of Congress are justified in these limited circumstances, and a more searching judicial review would be more respectful of Congress's lawmaking function than would an expansion of presidential nonenforcement of constitutionally objectionable statutes.

As the HIV provision well illustrates, presidential non-enforcement at times will offer the surest means of preventing the enforcement of an unconstitutional law, and yet constraints imposed by the constitutional structure, properly interpreted, will compel the President to enforce the law. This proposition may seem less surprising when considered in light of the following rationale the Supreme Court has offered for the deferential review the judiciary affords most

200. FCC v. Beach Communications, 508 U.S. 307, 315 (1993). 
congressional statutes:

The Constitution presumes that, absent some reason to infer antipathy, even improvident decisions will eventually be rectified by the democratic process and that judicial intervention is generally unwarranted no matter how unwisely we may think a political branch has acted. ${ }^{201}$

Only by faithful adherence to this guiding principle of judicial review of legislation is it possible to preserve to the legislative branch its rightful independence and ability to function. ${ }^{202}$

Presidential non-enforcement policy should aim to encourage rectification "by the democratic process" of what the President views as constitutional errors and "to preserve to the legislative branch its rightful independence and ability to function." Our constitutional structure is best served by the President and Congress thoughtfully promoting their views about the meaning of the Constitution through the lawmaking process: reviewing pending bills for constitutional problems and curing problematic provisions, voting against and vetoing bills that contain constitutionally objectionable provisions, and repealing unconstitutional laws. Where the lawmaking process fails to uphold the Constitution, as it sometimes will, judicial review, though imperfect, typically is the appropriate remedial process. The President should refuse to enforce a statute he believes unconstitutional only when he is specially situated to protect important constitutional norms without undermining the integrity of the lawmaking process.

201. Vance v. Bradley, 440 U.S. 93, 97 (1979), quoted in Beach Communications, 508 U.S. at 314.

202. Lehnhausen v. Lake Shore Auto Parts Co., 410 U.S. 356, 365 (1973), quoted in Beach Communications, 508 U.S. at 315. 